This document is the Accepted Manuscript version of a Published Work that appeared in final form in:

G.Pardo, A. del Prado 2020. Guidelines for small ruminant production systems under climate emergency in. SMALL RUMINANT RESEARCH. 193. DOI (10.1016/j.smallrumres.2020.106261).

(C) 2020 Elsevier B.V.

This manuscript version is made available under the CC-BY-NC-ND 3.0 license http://creativecommons.org/licenses/by-nc-nd/3.0/

\title{
Guidelines for small ruminant production systems under climate emergency in
}

\section{Europe}

G. Pardo ${ }^{a}$, A. del Prado $a$

${ }^{a}$ Basque Centre for Climate Change (BC3), Edificio Sede № 1, Planta 1ㄹ, Parque

Científico de UPV/EHU, Barrio Sarriena s/n, 48940 Leioa (Bizkaia)

Corresponding author: Agustin del Prado. Email: agustin.delprado@bc3research.org

Short title: Small ruminants under climate change in Europe

\begin{abstract}
Projected climate change will involve an additional threat for the sustainability of small ruminant production systems in Europe. Aiming to understand its implications, we conducted a literature review on climate change interactions with sheep and goat systems. The review first identifies the main potential impacts on productivity at the animal level (heat stress effects) and at the forage level (quantity and quality). Results from analysed studies suggest that heat stress thresholds for small ruminants could be higher than previously indicated, although they still will be affected during projected heatwaves. At the forage level, the potential positive effect of $\mathrm{CO}_{2}$ fertilization will probably be counteracted in most of the cases due to extreme weather events and other limitations. Based on that findings, the review analyses the most suitable adaptation strategies on animal heat stress and pasture production. Particular attention is paid to integrated approaches, providing co-benefits at
\end{abstract}


different levels. Finally, structural and practical challenges affecting small ruminants' sustainability in a climate change context are discussed, together with potential synergies and trade-offs among different policies and/or strategies. According to the information reviewed, small ruminant systems could be particularly vulnerable to environmental changes, as they are often produced in harsh areas under already severe circumstances. At the same time, they have particular features that could involve advantages against other livestock systems to cope with -and fight againstfuture climatic conditions. Consequently, they should play a important role for the climate change adaptation and mitigation options within the livestock sector.

Keywords: global warming; sheep; goats; climate change

\section{Introduction}

Future climate projections for Europe indicate a general warming trend and more variable patterns of precipitation, with an increase in frequency and length of dry periods and droughts (Jacob et al., 2014). Consequently, other abiotic variables will also be influenced, including increased likelihood and intensity of fires and floods and alteration of nutrient cycles. Such changes will inevitably affect livestock production, both the animals directly and the production system more widely. In this context, small ruminant systems are subject to specific challenges regarding their future. On one hand, they could be particularly vulnerable to environmental changes, as a large share of the production is held in marginal lands and/or semiarid conditions. Yet on the other hand, small ruminants have features (e.g. weather 
resistance, grazing/browsing abilities) that can involve competitive advantages and opportunities against other livestock species in the face of a changing climate.

Aiming to understand the potential influence of climate change (CC) in small ruminant farming in Europe, we here conduct an analysis of information available on $\mathrm{CC}$ interactions and weather effects on sheep and goat systems, involving direct impacts on animal productivity mainly, but also indirectly, via feed resources availability and disease occurrence. Other important aspects, e.g. welfare, although superficially mentioned, are beyond the scope of this study. The main objective of this study is to estimate the general expected impacts of CC in the sheep and goat systems, but also to provide guidelines about how the sector could adapt to -or exploit- them. Accordingly, a set of guidelines including main CC adaptation strategies, but also synergies with CC mitigation, are discussed, both at practical and strategic level (i.e. policy), so the future role of European small ruminants in the context of CC can be adequately considered.

\section{Climate change effects on small ruminant systems: animal and fodder level}

Animal level

Heat stress

In addition to warming trends, future climate scenarios predict an increase in the frequency and duration of heat waves in Europe (Jacob et al., 2014), particularly in south-central regions. As a consequence, heat stress (HS) will be one of the most important factors affecting sheep and goat production.

The general responses to HS in small ruminants include a number of metabolic, physiological and behavioural changes, such as raised respiration rate and rectal temperature, sweating, panting, increase drinking and reduction of feed intake (Marai 
et al., 2007). Nevertheless, sheep and goats are considered less susceptible to HS than other domesticated species (Lu, 1989), which could provide them a competitive advantage under future $\mathrm{CC}$ scenarios.

The literature describes thermoneutral zone (TNZ) for sheep between $12^{\circ} \mathrm{C}$ and $25^{\circ} \mathrm{C}$. A higher HS threshold $\left(28^{-}-30^{\circ} \mathrm{C}\right)$ can be expected for goats, due to specific adaptation mechanisms (Lu, 1989; Al-Dawood, 2017). Still, these ranges are often exceeded during heat waves in Europe, and that situation will become more frequent in the future.

The risk of HS is often estimated by the temperature-humidity index (THI), which accounts for the combined effects of ambient temperature and relative humidity $(\mathrm{RH})$. Based on this index, the following thresholds have been proposed for small ruminants $(\mathrm{THI}<22.2=a b s e n c e$ of $\mathrm{HS} ; 22.2$ to $<23.3=$ mild $\mathrm{HS} ; 23.3$ to $<25.6=$ moderate HS; >25.6 severe HS) (Marai et al., 2007).

In the present work, a revision of literature involving small ruminants and HS has been conducted. Detailed methodology is described in the Supplementary Material S1. First, we selected studies monitoring ambient conditions and animal-based indicators related to signs of $\mathrm{HS}$, namely respiration rate and rectal temperature.

THI was applied as an indicator for the degree of HS caused by weather conditions. The formula proposed by Marai et al 2007 was used:

$\mathrm{THI}=\mathrm{db} \circ \mathrm{C}-\{(0.31-0.31 \mathrm{RH})(\mathrm{db} \circ \mathrm{C}-14.4)\}$

where $\mathrm{db}{ }^{\circ} \mathrm{C}$ is the dry bulb temperature $\left({ }^{\circ} \mathrm{C}\right)$ and $\mathrm{RH}$ is the relative humidity $(\mathrm{RH} \%) / 100$.

Relationship of both parameters, respiration rate and rectal temperature, with $\mathrm{THI}$ followed a quadratic function (Figure 1 and 2), indicating that at high THI values, an increased response of the mechanisms to cope with HS is triggered. Results agree 
generally with the ranges reported by Marai et al. (2007), although they show a higher HS threshold. According to Figures 1 and 2, early signs of HS would appear at a $\mathrm{THI}$ range among 23 to 25 , which would suggest that small ruminants would be capable to cope with hotter conditions than previously estimated.

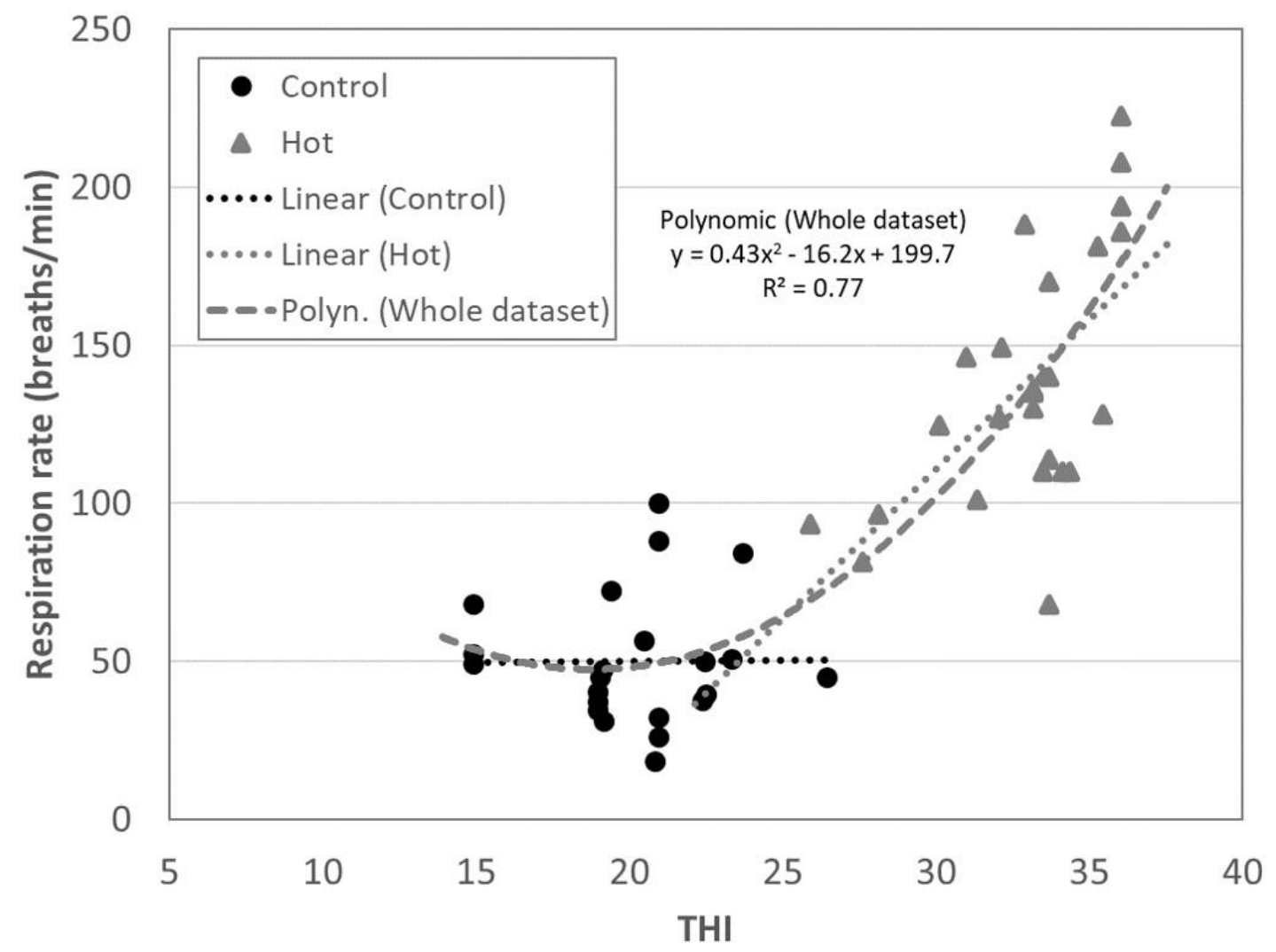

Figure 1 Relationships between respiration rate and THI from reviewed studies on small ruminants

Nevertheless, ultimately the vulnerability of sheep and goats to HS will be determined not only by ambient conditions, but also by other factors like the animal's physiological stage (e.g. pregnancy, lactation) (Hamzaoui et al., 2013), or the specific breed (Brown et al., 1988). Analysed datasets indicate that dairy animals tend to be more susceptible to HS than those from meat systems. While both groups would trigger a similar level of response (i.e. increase in respiration rate) to cope with HS (Figure S1), in the case of dairy animals a higher increase in rectal temperature 
is observed (Figure S2). This would suggest that cooling mechanisms activated are less capable to dissipate the body heat produced by dairy animals, which would be in accordance with several authors pointing out milk production as an important metabolic heat strain (Hamzaoui et al., 2013; Carabaño et al., 2017).

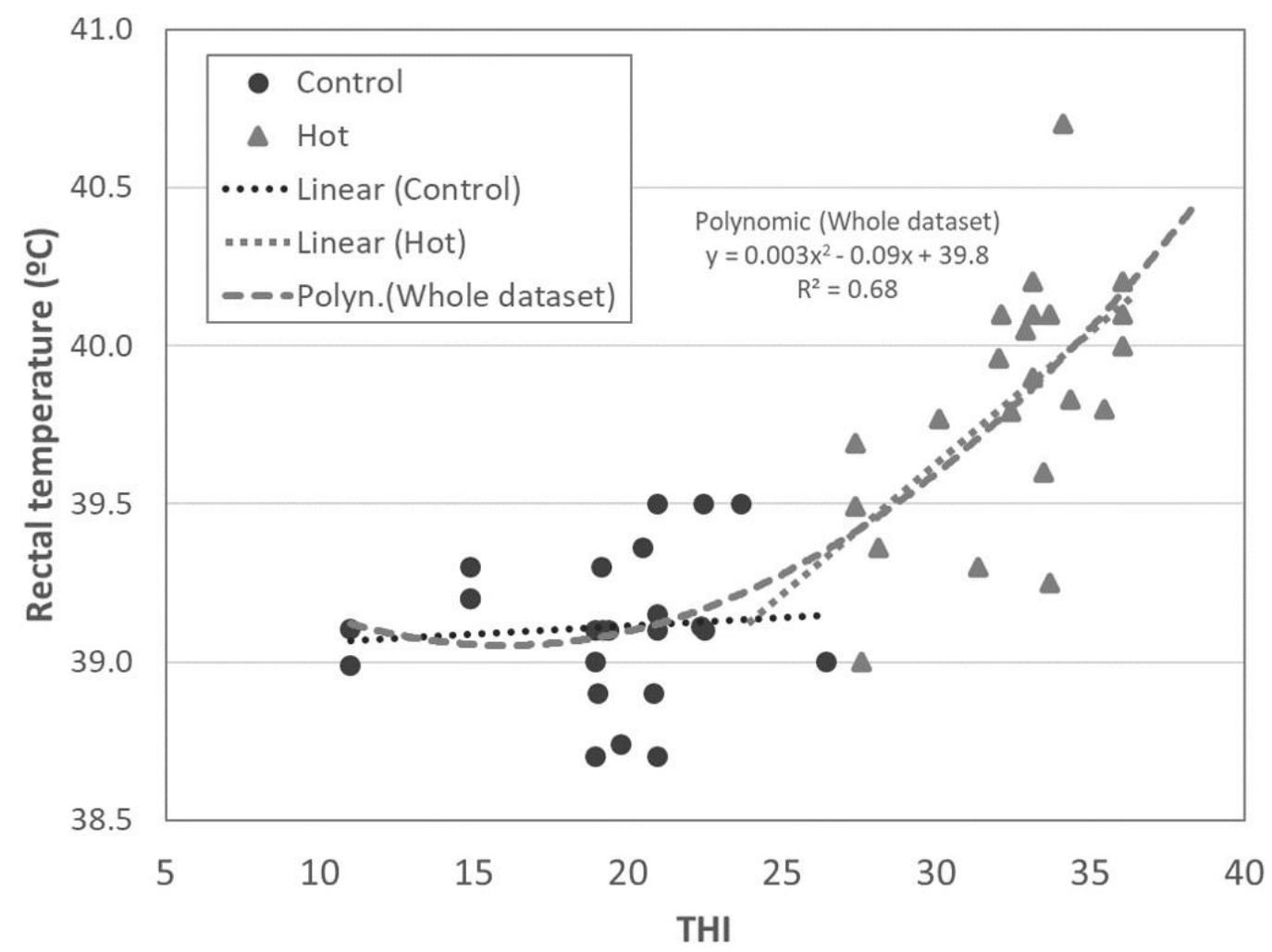

Figure 2 Relationships between rectal temperature and THI from reviewed studies on small ruminants

\section{Effects of heat stress on production}

Decreased productivity under HS has traditionally been attributed to the feed intake (FI) reduction observed in animals exposed to a high thermal load (Salama et al., 2014). However, recent studies have pointed out that feed intake and production can sometimes have dissimilar responses to HS, indicating that different mechanisms could be involved in the productivity reduction associated to HS (Mahjoubi et al., 2014). 
While a number of studies have analysed the FI decrease in ruminants under HS, ranges for sheep and goats are still unclear. A specific review of the literature about this topic was conducted (Supplementary Table S2). As a result, a relationship between $\mathrm{THI}$ and $\mathrm{FI}$ was established (Figure 3), showing a gradual response which leads to significant $\mathrm{FI}$ reductions (10-25\%) at severe HS conditions (THI>25.6), contrasting with previous linear approaches for this issue.

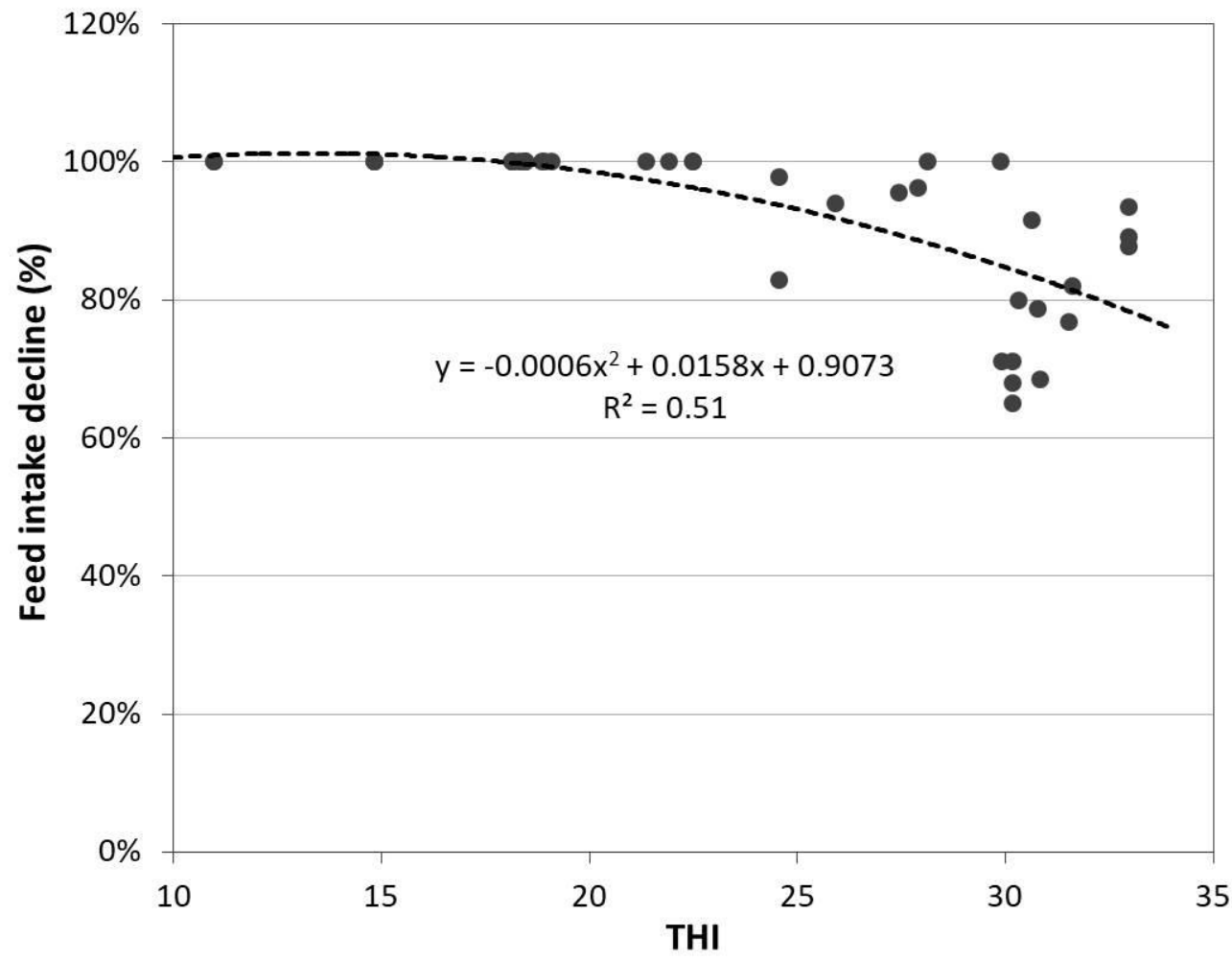

Figure 3 Relationship between feed intake decline (\%) and THI from reviewed studies on small ruminants

Studies with lambs show that HS impairs growth rate, reducing daily gain (Darcan and Cankaya, 2008; Mahjoubi et al., 2014) but also affects pregnancy stage, decreasing the birth weight while increasing the embryo mortality rate (Romo-Barron et al., 2019), thus leading to a efficiency loss at farm level. 
In dairy sheep and goats, a number of studies have reported decreases on milk production associated to HS conditions. However, in other cases, the effect has resulted on a decline on milk quality, like fat or protein content.

A review of the available trials about this topic was conducted (Details described in Supplementary Material S1 and Table S3). The collected data were normalized into fat and protein corrected milk (FPCM) to capture together the effects on milk production and quality (Figure 4). Results indicate a gradual decline of the FPCM productivity, in the range of $2-5 \%$ at mild HS levels, up to $20 \%$ at severe HS conditions.

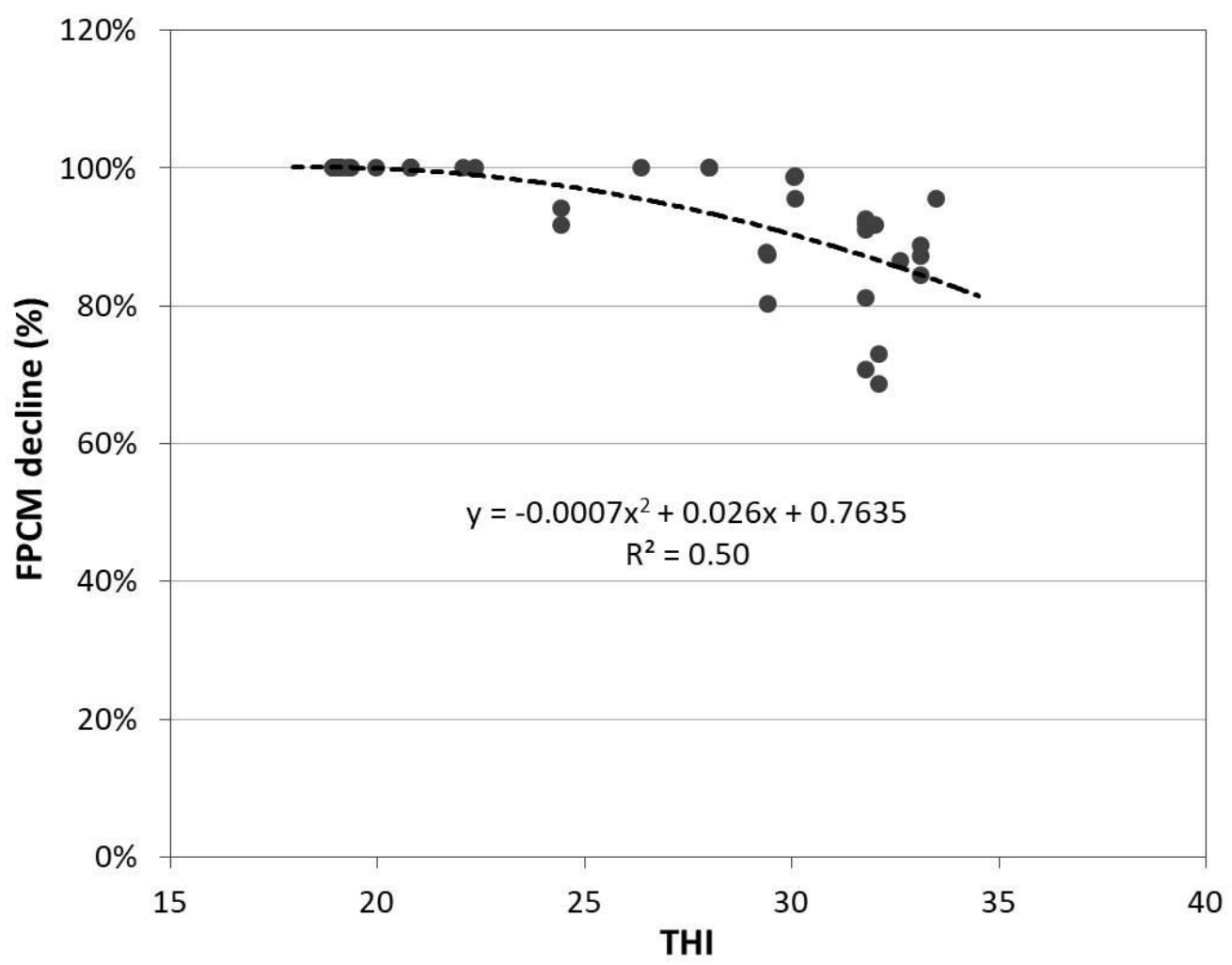

Figure 4 Relationship between fat and protein corrected milk (FPCM) production decline (\%) and THI from reviewed studies on small ruminants

This involves a decline of about $1.5 \%$ in milk yield for every increase in one point of THI, comparatively higher than previous estimates (Salama et al., 2014). 
Further negative effects of HS on product quality has also been observed in sheep and goat meat (Devine et al., 1993) and milk (Sevi and Caroprese, 2012), affecting, for example, milk coagulating properties, and consequently, the cheese-making process and control operations (Albenzio et al., 2004).

\section{Effects of heat stress on fertility and reproduction}

Heat stress impacts negatively fertility in small ruminants. For male animals, both the quantity and quality of sperm is reduced and the libido and fertilization capacity are significantly impaired (Kukovics, 2016). In female, it affects the ovarian function, by reducing the oestrous duration and delaying the oestrous cycle, thus affecting conception probability (Romo-Barron et al., 2019).

Different factors will determine the specific response to HS at animal level, such as physiological status, breed or HS exposure time. Nutrition, for example, has been identified as one of the main factors affecting ovulation rate and sexual activity, and modulating reproductive endocrine functions (Forcada and Abecia, 2006). Changes in feed and forage (quantity and quality) due to CC may therefore add their own impacts on small ruminants' systems, playing an important role not only on productivity, but also on reproduction issues.

\section{Effects of heat stress on disease occurrence}

Extreme events (e.g. heat waves or flooding) can severely weaken the animal immunity and udder health and speed up the development rates of pathogens and prevalence of infectious diseases (Escarcha et al., 2018). Moreover, climate change, indirectly, has been found to also increase persistence and abundance of disease vectors and parasites and host resistance to infectious agents (Escarcha et al., 2018). 
The way climate change-driven diseases may affect different small ruminants compared with other livestock species depends on the characteristics of the animals but also on the type of production systems. Whereas intensive systems are expected to be more vulnerable to health impacts of climate changes through heat stress, both intensive and extensive systems will be severely affected by new or expanded exposure to pests and disease. (Henry et al., 2018).

The effect of climate on vector-borne diseases from small ruminants has been studied and the life cycle and geographical distribution of insects and ticks and, therefore, on arthropod-borne infections (mainly virus, bacteria and protozoa) have been documented (Marino et al., 2016). Sheep and specially goats, more in warm and moist climates, are known to be very susceptible, compared to other livestock, to internal parasites as they tend to graze closer to faecal drops, specially sheep, are slow to develop immunity (specially goats), and at parturition, they have a temporary loss of immunity. The production system will affect the age structure of the sheep population, stocking density, seasonality of grazing and many other factors that underpin the epidemiology of, for example, nematode infection (Sotiraki et al., 2013). Tick-borne diseases Ixodes ricinus, the sheep tick, and midge-borne diseases, like the bluetongue, have been found to be expanded its geographical range (shifting farther north and East) and seasonal activity in Europe over the past decade. These changes have been, partly, related to milder winters and prolonged spring and autumn seasons (Caminade et al., 2019).

Plant-borne helminth infections (e.g. caused by gastrointestinal nematodes (GIN) and liver fluke) are currently one of the main health and productivity issues in sheep farms worldwide (Sargison, 2016). The impact of weather and climate on the dynamics of parasitic worms such as those leading to liver fluke in sheep (Fasciola 
hepatica) has been studied in some countries in Europe (e.g. UK). Transmission of this parasite has been found to be seasonal in most countries (Caminade et al., 2019) and favoured by wet and mild/warm climatic conditions on grasslands systems (Caminade et al., 2019).

\section{Plant level}

One of the most important impacts of $\mathrm{CC}$ on small ruminant systems in Europe is expected to be through changes in forage supply. Plant growth potential relies primarily on plant's biological characteristics and ambient conditions, such as temperature, solar radiation and carbon dioxide $\left(\mathrm{CO}_{2}\right)$ concentration. However, ultimate plant productivity (quantity and nutritional quality) is influenced by a number of limiting factors (e.g. nutrients, soil water) and stressors (e.g. ozone $\left(\mathrm{O}_{3}\right)$ concentration, pests), many of them directly and/or indirectly affected by CC.

\section{Effects of elevated $\left[\mathrm{CO}_{2}\right]$ and interactions with other factors}

The increase in $\mathrm{CO}_{2}$ concentration $\left[\mathrm{CO}_{2}\right]$ in the atmosphere is the main cause of the greenhouse effect linked to $\mathrm{CC}$. Many studies have confirmed the so-called $\mathrm{CO}_{2}$ fertilisation effect enhancing plant growth (Nowak et al., 2004; Ainsworth and Long, 2005). On grassland ecosystems, the stimulatory effect of doubling the ambient $\left[\mathrm{CO}_{2}\right]$ increases aboveground production by about $10-20 \%$ on average (Lee et al., 2013), although the effect may vary widely depending on the species, system and seasonal conditions. When no other climatic factors are considered, trees and shrubs have the greatest response to elevated $\left[\mathrm{CO}_{2}\right]$, whilst among non-woody plants, species that fix $\mathrm{N}_{2}$ (i.e. legumes) are favoured over non-fixing species (i.e. graminoids) (Nowak et al., 2004; Ainsworth and Long, 2005; Dellar et al., 2018). 
Higher temperature also tends to increase plant growth, although beyond an optimum the effect starts to decrease. In Europe, where an overall warming trend is expected (Jacob et al., 2014), this effect could enhance pasture yields in temperate and cold Northern regions (Höglind et al., 2013), while in warmer areas some species may reduce its potential.

Nevertheless, the ultimate response of grassland ecosystems will be defined by the interacting processes in the soil-water-plant system, where many different factors are involved. Water availability is probably the most critical constraint to plant growth, even counteracting the enhanced productivity associated with rising atmospheric [CO2] or temperature (Dellar et al., 2018). Hence, changes in rainfall patterns projected for all European regions will become very relevant, but particularly damaging in the Southern region. Combination of longer dry spells and warmer temperatures during certain periods will reduce soil moisture by enhancing evapotranspiration. As a result, the positive $\mathrm{CO}_{2}$ fertilisation effect on plant production can be significantly reduced or even removed in most of the cases (Obermeier et al., 2017).

Nutrients also play a key role in the extent of the $\mathrm{CO}_{2}$ fertilisation effect. Managed pastures with a high external input of $\mathrm{N}$ have greater productivity when $\left[\mathrm{CO}_{2}\right]$ increases but little or negligible response has been observed in pastures with low $\mathrm{N}$ supply (Nowak et al., 2004). Increased biomass production under elevated $\left[\mathrm{CO}_{2}\right]$ may therefore not be sustained in natural and semi-natural ecosystems due to nutrient limitations.

In terms of nutritional quality, there does not appear to be any significant effect of elevated $\left[\mathrm{CO}_{2}\right]$ on forage digestibility (Dumont et al., 2015). With regards to protein content, experiments have shown that conditions linked to enhanced productivity (i.e. 
elevated $\left[\mathrm{CO}_{2}\right]$ ) usually lead to reduced protein content in forage species. In contrast, reduced water availability, which often results on a decrease in productivity, tends to increase protein content (Dellar et al., 2018). Thereby, under future climate conditions, the potential increase of pasture productivity projected in regions like Central and Atlantic Europe, would be accompanied by a decrease in the protein content of non-leguminous plants.

This effect could be partially counteracted by changes in plant species composition, as a shift towards a higher content of legumes in pastures is expected (Allard et al., 2003). However, particular management and grazing abilities of small ruminants must be carefully considered, as they can have a crucial influence. For example, in a long-term pasture study, the relative proportions of forbs and legumes only increased in the first years, as selective defoliation due to grazing sheep countered the faster growth rates of forbs and legumes in response to elevated $\left[\mathrm{CO}_{2}\right]$ (Newton et al., 2014).

\section{Effects of climate on other stressors}

Ozone $\left(\mathrm{O}_{3}\right)$ is a harmful plant pollutant, which can cause damage to forage species, as well as increased sensitivity to pests and pathogens. Although emissions of $\mathrm{O}_{3}$ precursors are decreasing in Europe, $\left[\mathrm{O}_{3}\right]$ level is predicted to increase due to emissions in other parts of the world (Fuhrer, 2009). Several experiments have found that clover species tend to particularly suffer from increased $\left[\mathrm{O}_{3}\right]$, which will influence changes in pasture composition (Fuhrer, 2009).

Furthermore, higher temperatures will increase the multiplication rate of soil-borne pathogens, which could enhance the incidence of diseases affecting forage plants. Warming conditions will also mean that insects extend their ranges to higher 
latitudes and altitudes, and could also expand the range of plants they consume (Bale et al., 2002).

\section{Climate change adaptation strategies for small ruminant systems in Europe}

Coping with heat stress at animal level

Preventing/mitigating heat stress

Some measures can help animals to deal with hot conditions, by reducing exposure or by enhancing heat losses. Physical protection with artificial or natural shade is one of the most cost-effective measures outdoors to prevent HS. Solar radiation affects small ruminants, increasing thermal load and affecting welfare, ruminant behaviour and productivity (Alvarez et al., 2013). Hence, providing shade through trees or artificial shelters is highly recommendable, particularly in feeding areas, in order to avoid drops in consumption.

Improving conditions in barns is another strategy that can prevent HS. Keeping an adequate stocking density and airspace, or meeting the larger needs (in quantity and frequency) of drinking water during heat waves, are important factors to consider. Other practices, such as shearing and polling/disbudding, and minimal handling of animals during heatwave periods are also recommended (Pennisi et al., 2004).

Building design and orientation are also important: east-to-west is better than northto-south to reduce sunlight exposure, while an alignment perpendicular to prevailing winds captures better the breeze. House dimensions, in particular width, are critical to promote air movement, minimising the inside to outside temperature gradient and maximising heat loss through natural convection.

The use of specific cooling devices has proven to be an effective measure for enclosed animals at particularly hot environments. Forced ventilation and spray 
cooling systems has been shown to alleviate HS, improving weight gain, milk yield and welfare in ewes (Albenzio et al., 2004) and goats (Darcan and Güney, 2008; Darcan and Cankaya, 2008).

\section{Nutritional management under heat stress}

An animal with poor nutritional status will be more susceptible to environmental stresses of all kinds. Ensuring a nutritionally balanced diet is therefore an easy way to improve sheep and goat resistance to challenging conditions. Moreover, diet management will need to be modified in order to adapt to extreme heat events. For those periods, there are potential strategies to ameliorate the effect of heat on animal performance.

During daytime periods of high ambient temperature, small ruminants can experience changes in feeding behaviour, leading to reductions in the feeding frequency and daily intake. Changes in feeding regime can help to alleviate this effect, for example by increasing number of meals and shifting meals to late afternoon/evening and placing the feed in shaded areas (Sevi and Caroprese, 2012). Use of high energy density diets (e.g. higher concentrates vs forage, fat) is a good practice, in order to balance reduced feed intake and increased energy demand for thermoregulation. Moreover, feeding fat is associated with reduced metabolic heat production per unit of energy fed and compared to starch and fibre, fat has a much lower heat increment in the rumen (Van Soest, 1982).

The use of protein with low rumen degradability is also an option, as it allows to balance increased $\mathrm{N}$ catabolism. As has been shown for cereal-based sheep, slow fermenting grain can reduce metabolic heat and help ameliorate HS (GonzalezRivas et al., 2016). 
Use of specific supplements can also provide benefits. Whole flaxseed has been shown to help immune function and physiological responses of sheep (Caroprese et al., 2012). Some nutraceuticals (e.g. mineral and antioxidant supplementation) may also be beneficial against the negative effects of HS in sheep (Chauhan et al., 2014) and to improve productive and reproductive functions (Sitzia et al., 2015).

\section{Genetic selection and adoption of heat resistant breeds}

Those breeds that originate in tropical and arid areas are considered to cope better with HS, partly due to anatomical and morphological traits better adapted to hot conditions, such as long ears, large body surface, skin thickness, length of hair and high sweating capacity of sweat glands, among others. Moreover, their low body mass and low metabolic requirements allows them to minimise their water and maintenance requirements. Hair sheep and fat-tailed sheep tend to tolerate heat better than wooled and thin-tailed sheep, while goats with loose skin or floppy ears tend to be most heat tolerant. Animals with light coloured hair/wool and pigmented skin are also better adapted to hot conditions (Al-Dawood, 2017). In contrast, the shorter legs and bodies; short, thick ears, tight skin and dense fleeces of most Northern European breeds makes them comparatively poor at resisting HS.

Although swapping to more resistant breeds is one option, this can have its own problems. Breeds native from hot and arid regions often show low productivity. This is due to adaptation to harsh environments, but also to the lack of selection programmes in these regions. In many cases, the large productivity gap with European populations may not justify the introduction of breeding stock from hot areas in crossbreeding programs, although this might be an alternative to selection under more extreme conditions (Al-Dawood, 2017). 
Selection goals in Europe have mainly focused on high productivity, which have resulted in animals increasingly more susceptible to HS. In fact, when analysing historical milk records, genetic antagonism has been found between productivity and heat tolerance, even for local breeds of dairy sheep and goats (Carabaño et al., 2017). Inclusion of heat tolerance traits in the current selection programs of small ruminants may provide a useful tool to establish climate-oriented farming systems in Europe. However, difficulties for defining heat tolerance criteria and quantifying adequate levels for the chosen traits, may challenge the development of selection programs. Overall, an equilibrium between productivity and adaptation to high heat loads in selection or crossbreeding programs have to be valued for each system of production.

\section{Adaptation to increased disease occurrence}

With the increasing problem of anthelmintic resistance to drugs in recent decades (Van Dijk et al., 2010), more emphasis is required to limit the level of parasitism below acceptable limits while delaying the emergence of drug resistance. This will require an integrated approach which do not intend to lead to parasite-free animals but rather, prevent clinical disease and production losses. Measures will be required at different levels of the farm management including other alternatives to commercial anthelmintic drugs, such as vaccines (Morand-Fehr and Boyazoglu, 1999), host resistance, and grazing management. Good pasture management, in fact, is one of the major means to limit the intake of infective larvae by animals, for example, by the use of parasite-free fields, pasture rotations, and alternation of grazing animals (Morgan et al., 2018). Also, using alternative forages with anthelmintic value (e.g. rich-tannin forages) appear to be a promising option (Morgan et al., 2018). Other 
measures include using resistant breeds, genetic selection for resistance and resilience to parasite infection (Joy et al., 2020) and early or out-of-season lambing/kidding. The development of cheap and efficient methods of animal identification, registration and control of movements which would allow timely preventive measures in daily operations will also be helpful (Durmus et al., 2019).

\section{Adapting pastures/forages to a changing climate}

\section{Enhancing diverse pastures}

Biodiversity acts as a safeguard of ecosystem functioning, thus promoting a more stable and resilient ecosystem against fluctuations of climatic conditions. Accordingly, studies indicate that multi-species mixtures contribute to the resistance of grassland yields to extreme events (e.g. droughts), which are expected to become more frequent and severe in most European regions (Hofer et al., 2016).

Increasing mixed legume-grass pastures is also a good measure to adapt to potential shortages of global protein sources in Europe, or to face the expected decreased of protein content in non-leguminous plants under CC conditions (Dellar et al., 2018). Consistent yield benefits of mixed grass-legume swards have been reported across a wide range of climatic conditions and fertilization levels, generally outperforming monocultures (Kirwan et al., 2007). Moreover, legumes, when they are grown in pasture-crop rotations, can also reduce weed populations and break the life cycles of pests and diseases (Howieson et al., 2000).

Beyond the effects on grassland production, forages from mixed swards may also lead to a positive response at the animal level. Increased herbage voluntary intake has been observed in sheep when more diverse forage mixtures were provided (Niderkorn et al., 2015). The big challenge for legume-based grassland systems will 
be, however, persistence of legumes. Their relative abundance in mixed swards tends to decrease over time, especially under high $\mathrm{N}$ fertilisation levels (Lüscher et al., 2014), but other practices, in particular sheep grazing, also appear to have a detrimental effect on the legume proportion of mixed grasslands (Dumont et al., 2011). Different strategies have been shown to prevent this decline, such as: adjusting fertilisation dosages, increasing defoliation/cutting frequency, or through an adequate pre-selection of species for enhancing more diverse mixed grass-legume swards, considering their competitive abilities relative to each other (Lüscher et al., 2014; Brophy et al., 2017).

\section{Reducing tillage}

Implementing changes in tillage practices could be another adaptation measure applicable across different climatic regions and systems. Reduced tillage increases resilience to CC through improved soil fertility and increased capacity for water retention in the soil, and should generate improvement in the long-term productivity potential. Reduced tillage at pasture reseeding has been observed to prevent the deterioration of pasture quality and promote $\mathrm{C}$ sequestration and preservation in pastures, plus is considered to be more effective under conditions of water deficit.

\section{Plant breeding}

Longer term adaptations can also be developed through improved plant breeding. New forage resources are required that are adapted to higher temperatures, increased $\left[\mathrm{CO}_{2}\right]$ and drought periods (Hopkins and Del Prado, 2007). This might be achieved through exploitation of traits for dehydration tolerance and summer dormancy, either in novel species or for introducing traits into existing widely used 
grasses and legumes (Volaire et al., 2014). Particular emphasis should be also on targeting plant traits that can deal with more than one abiotic stressor (e.g. grasses that can both tolerate drought and flooding: (Loka et al., 2016)).

\section{Dealing with scarcity of feed resources}

\section{Smart grazing and forage management}

For small ruminant systems largely reliant on grazing, $\mathrm{CC}$ in Europe will require livestock managers to deal with increased inter and intra-annual variability in forage availability dynamics. In rainy areas, ability to manipulate forage quantity and quality through grazing management, fertilisation and use of seeded forages will become very important. Spring plant growth, provided sufficient water availability, and winter production is likely to benefit from mild climate conditions. For southern, drier areas, adjusting the match-up between seasonal nutrient demand and supply through manipulation of an animal's physiological state or through different mobility patterns will be more appropriate (Martin et al., 2014). In fact, forage resources usually stored for over-wintering livestock could be partially redistributed in summer to deal with increased risk of forage deficit.

The benefits from management-intensive grazing strategies, like rotational and multipaddock grazing, will become especially relevant in future scenarios. These practices not only lead to increased pasture yield and utilisation, but they also reduce livestock selectivity towards more palatable foods, thus enabling sustainable sward diversity in the long term (i.e. legume persistence) and providing advantages in terms of animal nutrition (Provenza et al., 2003). Likewise, mixed grazing (i.e. mixing sheep and/or goats with cattle) has also been shown to provide specific advantages 
to small ruminant systems in terms of pasture utilisation, animal weight gain and control of parasite burdens (D'Alexis et al., 2014).

\section{Alternative feed resources}

A number of by-products from agricultural, food processing, forestry and bioenergy activities could be used for feeding small ruminants as an adaptive response to forage supply seasonal constraints (Salami et al., 2019). Large volumes of agroindustrial by-products are produced in Europe every year which are not always adequately valorised. Among them, olive cake, citrus pulp and tomato pomace have been shown to be particularly suitable for small ruminant feeds (Table 1). Other agrifood by-products have also been successfully tested and its potential use deserves to be further explored (Supplementary Table S4).

Table 1 Alternative feed sources suitable for small ruminants and estimated availability in Europe

\begin{tabular}{|c|c|c|}
\hline $\begin{array}{l}\text { Alternative feed } \\
\text { sources }\end{array}$ & $\begin{array}{l}\text { Availability } \\
\text { in Europe } \\
\text { (kTon/yr) }\end{array}$ & References in small ruminants $^{1}$ \\
\hline Olive cake & 8190 & $\begin{array}{l}\text { Abbeddou et al 2011, Arco-Pérez et al 2017, Cabbidu et al } \\
2004 \text {, Chiofalo et al 2004, Hadjipanayiotou et al 1999, Molina- } \\
\text { Alcaide et al 2010, Ben Salem and Znaidi } 2008\end{array}$ \\
\hline $\begin{array}{l}\text { Tomato by- } \\
\text { products }\end{array}$ & 2601 & $\begin{array}{l}\text { Abbeddou et al 2011, Arco-Pérez et al 2017, Di Francia et al } \\
\text { 2004, Razzaghi et al 2015, Romero-Huelva et al 2013; } \\
\text { Romero-Huelva et al 2013b; Romero-Huelva et al 2017, Ben } \\
\text { Salem and Znaidi 2008, Denek and Can } 2006\end{array}$ \\
\hline Citrus pulp & 1073 & $\begin{array}{l}\text { Fegeros et al 1995, Romero-Huelva et al 2013; Romero- } \\
\text { Huelva et al 2017, Bueno et al 2002, Caparra et al 2005, } \\
\text { Lanza et al 2001, Scerra et al } 2001\end{array}$ \\
\hline $\begin{array}{l}\text { Other fruit by- } \\
\text { products }\end{array}$ & 1301 & $\begin{array}{l}\text { Razzaghi et al } 2015 \text {, Sedighi-Vesagh et al } 2014 \text {, Volanis et al } \\
2004 \text {, Eliyahu et al 2015, Pirmohammadi et al } 2006\end{array}$ \\
\hline $\begin{array}{l}\text { Other vegetable } \\
\text { by-products }\end{array}$ & 3189 & $\begin{array}{l}\text { Nudda et al 2006, Romero-Huelva et al 2013; Romero-Huelva } \\
\text { et al } 2013 \mathrm{~b}\end{array}$ \\
\hline
\end{tabular}

${ }^{1}$ The complete reference list is provided in the supplementary material (Table S4) 
Despite this, poor nutrient balance, seasonality and difficulty for handling and longterm conservation as fresh material are crucial issues that constrain their wider use as animal feed. Preservation through different techniques like pelleting, ensiling or manufacture of feed blocks can help to overcome these difficulties, expanding the potential for including a broader range of agro-industrial by-products in small ruminants diets (Ben Salem and Smith, 2008).

Tree leaves and shrubs further offer an alternative forage supply, especially during periods when grassland growth is limited or dormant due to unfavourable weather conditions (summer/autumn). Various tree species have been identified of interest for small ruminants as a source of proteins and macro- and micronutrients. According to reviewed studies, leaves from white mulberry (Morus alba), ash (Fraxinus excelsior), alder (Betula alba), robinia (Robinia pseudoacacia) and lime trees (Tilia platyphyllos) are especially suitable to be included in ruminants diet (Luske and Van Eekeren, 2015), although a number of fodder shrubs have also been identified for their potential in Mediterranean systems (Eichhorn et al., 2006).

\section{Integrated approaches}

Agroforestry systems

Besides serving as an additional feed source, planting forage trees in grazing areas (introduction of silvo-pastoralism) can also provide shelter, as previously mentioned, preventing HS and improving animal welfare. Moreover, trees could involve important synergies for pasture production, especially in harsh environments, as they can extend the seasonality of the understory production by buffering the microclimate under the canopy and by enhancing an uneven distribution of nutrients. 
Southern Europe already hosts several oak-based agroforestry systems (e.g. Dehesa-Montado in the Iberian Peninsula) that have been shown to be good examples of highly resilient, productive and biodiverse farmed landscapes (Hopkins and Del Prado, 2007). In parts of temperate Europe there are also wood pastures systems, that provides shelter for sheep in both, winter and summer. Similarly, hedgerow systems found in central Europe can be considered examples of the integration of trees with pastures for livestock production.

Fire risk control

Grazing with small ruminants has been proposed as a valuable tool for the prevention of fire risks in different landscapes and systems. They not only allow to control the accumulation of flammable vegetation, but they can also be managed for clearing and maintaining firebreaks, especially in remote areas or with steep slopes, where they can be an alternative to mechanical methods. If adequately valued, this activity could involve an additional income to the farm while providing an alternative source of feed.

The role of small ruminant grazing for the preservation of a number of landscapes in Europe have been highlighted in several cases, like Atlantic heathlands (Jáuregui et al., 2009) or Mediterranean scrublands (Mancilla-Leytón et al., 2013). In these areas, arable farming is unfeasible and this system often represents the only way of productively using the land.

In Southern Europe, where more severe fire events are expected with the prospect of warmer and drier summers, silvopastoral systems involving goats are particularly indicated, being a browser species well adapted to feed on shrubby vegetation and arid climatic conditions. Besides avoiding vegetation accumulation, it can also help to reduce the shrub encroachment that will be enhanced under $\mathrm{CC}$ conditions. In 
contrast, in commercial forest plantations of Central/Northern Europe, sheep seem more suitable for controlling competing ground vegetation than other livestock ruminants, like cattle or goats, that may cause more damages to trees, by trampling or browsing respectively (Sharrow et al., 1989).

Cover crops

Cover crops are non-marketable plants grown to protect the bare soil, providing several benefits in terms of soil health, weeds control and nutrient balance. In the context of $\mathrm{CC}$, they can help to increase adaptive capacity against extreme rain events (i.e. soil erosion) and droughts (Alonso-Ayuso et al., 2014) while mitigating climate warming through changes in biogeochemical processes and albedo. However, their use is often limited as they do not involve immediate revenue for farmers. Coupling cover crops and small ruminant systems can offer interesting opportunities for both sides, either as an additional source of forage and as grazing management tool for plant growth control.

Structural and practical challenges affecting small ruminants' sustainability in a climate change context

The sector has been experiencing economic and structural changes in recent decades, mainly due to a decrease in livestock numbers (linked to changes in consumer trends and intensification of production), outbreaks of contagious diseases and policy changes. Climatic hazards are expected to add yet further challenges to this ongoing situation. 
At the EU level, several policy instruments are already available for helping the sector in its capacity to deliver a broad range of ecosystem services. Nevertheless, due to the numerous challenges that the sector is likely to undergo in the future it is becoming clear that the current level of support (e.g. the Common Agricultural Policy (CAP) post-2020) is likely to be insufficient, especially for systems that are more extensive.

Climate change in Europe, as previously mentioned, will require livestock managers to be more flexible in order to deal with increased variability in forage quality and productivity. One strategy may be to save forage in years that are more productive, which would demand for additional investment and costs for preservation technologies and storage. For pasture-based systems, the reduced grazing of animals in higher temperatures will necessitate provision of supplementary feed or reconciliation of the deficit with lower production levels. To guarantee future sustainability of small ruminant systems, farmers will therefore need coordinated support from different agents (e.g. regional to national governments, producers' associations, research institutions) providing both the financial instruments (e.g. insurance plans, credits for investments) and the technical guidance (e.g. agroclimatic forecasts, heat-resistant breeds) to adopt the necessary adaptation measures.

For optimising the role that policy instruments have on the sustainability of small ruminant systems, policies must be aligned with the strategies relating to a number of cross-cutting issues, including CC, environment, rural development, bio-economy, food security, research and public health. Co-benefits in different issues should be sought (e.g. emissions and health), while potential trade-offs or counter-acting objectives must be identified and assessed too. 
Climate-related policies, for adaptation and mitigation goals, should be evaluated within agricultural policies, so the synergies among the two are promoted and the possible trade-offs are minimised. Rural Development Programmes supporting small ruminant systems under disadvantaged conditions is an example of policy that can involve additional climate co-benefits through the ecosystem services provided, such as promoting the usage of underutilized land resources (scrub, wood land), helping to reduce fire risk through adequate grazing practices and contributing to preservation of landscapes that act as reliable carbon sinks (e.g. grasslands vs forests). The definition of areas with natural constraints (ANC) under the CAP provides one of the main instruments to compensate farmers producing in mountain areas or facing other specific disadvantages. This is crucial to prevent land abandonment and ensure agricultural land-use and landscape maintenance. However, as projected climatic hazards could have uneven effects on agricultural landscapes across Europe, updated criteria used for the designation of new ANCs should consider expected CC impacts when developing future ANC schemes.

Current and potential upcoming EU agricultural strategies are likely to both prevent the expansion of cropland in Europe (e.g. CAP discouraging the conversion from grassland to arable land) and to hinder agricultural land use expansion in other regions outside Europe. This will coincide with the anticipated decline and increasingly erratic local production of grains in temperate European countries under CC. Under this scenario of limited land use conversion and CC further affecting feed supply, the use of unexploited rangelands resources (scrub, woodland) will acquire particular relevance (Silanikove and Koluman, 2015). This would be especially interesting for countries that could support sheep and goat grazing systems through policy and designation of appropriate land uses. However, in this strategy, where 
obtaining limited production at the lowest possible cost is the aim, the use of welladapted native animal breeds will be instrumental.

Appropriate alignment of rural objectives within EU strategies linked to food safety and food security should also be considered. For example, while the ANC schemes of rural development programmes in the CAP aim to support the viability of smallscale farms in disadvantaged areas, the EU's food safety policies are often considered a regulatory constraint against such farmers commercializing their products (Bureau and Swinnen, 2018). Similarly, EU development policies in relation to global food security are in conflict with the alarming tendency to feed ruminants a greater amount of ingredients that could otherwise have been used directly in the human food chain (Mottet et al., 2017). In the face of a future with CC severely affecting the stability of food supply, livestock systems that are non-competitive with human food-chains should be promoted via policy. This would be useful to arrest this trend and provide a potential competitive advantage of pasture-based livestock systems over other ruminant systems or livestock sectors (e.g. monogastric animals).

Considering future feed limitations, there is also great potential for small ruminant production systems in Europe to replace some of their feed with by-products from agro-industry. Again, appropriate alignment of different policies (e.g. bio-energy) together with other related regulations (environmental, food safety) would, however, be required. Such a strategy would promote a circular economy, improve resource use efficiency of the systems involved and decrease competition for human-edible feed resources. Despite the potential benefits, in the near future competition amongst food, animal feed and bioenergy will most probably result in decreasing availability of by-products for feed in some European areas. Integrated modelling 
approaches and methodologies like life cycle assessment can help to decide the most favourable use of each by-product from an environmental point of view. Nevertheless, prioritisation must always consider the particular context of every case (downstream effects, pollution swapping, logistics).

Securing good water availability and quality will become a still greater challenge, especially in Mediterranean areas, where many competing uses (e.g. irrigation) have to be balanced. Whilst promoting mixed legume-grass pastures and grain legumes are good measures in order to adapt to potential shortages of protein sources in Europe, for the most widely used legume in European grasslands (white clover), water is a limiting factor and requires availability of soil $P$. This should be recognised in breeding and promotion of legumes for use in agricultural systems.

Research strategies can be an important instrument encouraging these practices and enhancing the development of CC-adapted grass and animal varieties with improved efficiency in the use of nutrients and resources. Effective knowledge transfer and demonstration activities should be emphasised when developing research schemes, in order to engage both public and private sectors in the communication of research results.

Health-wise, it will be instrumental that parasite control is fully integrated into the whole-farm economic context (Charlier et al., 2014) and farmers (and their advisors) understand and internalise the costs and benefits of novel treatment strategies (Morgan et al., 2018). Further advance through public funding will have to be made in order to deal with infectious diseases in terms of surveillance systems, disease and vector control measures, vaccine development, diagnostic tests, and mathematical risk modelling. Otherwise, infections will significantly hinder the export potential of many Mediterranean areas, for example. In the globalised world, the 
highest level of protection could be guaranteed only by the simultaneous and harmonized policies and practices in all parts of the world. However, more efficient regional cooperation in research and in the implementation of measures could be the great step towards safeguarding and protecting small ruminants' animal industry (Durmus et al., 2019).

Despite the many challenges for small ruminant systems in Europe, opportunities exist. Growing market demands for fresh dairy products have been identified as an opportunity for the sheep and goat sectors in some European countries (e.g. France). To meet international market demands would require both changes in milking season schedules (extending the season from earlier in autumn and later in summer) and targeting the milk to market sector where it is competitive (e.g. milk intended for protected designation of origin (PDO) cheese-making). Such changes would exacerbate the challenges that HS exert on overall productivity and reproduction performance, but, if appropriate adaptation measures are introduced to alleviate HS impact, the sector could still be in a good position to have a competitive advantage against the dairy cattle sector (Silanikove and Koluman, 2015).

\section{Conclusions}

Small ruminant production systems are subject to specific challenges regarding their future, and projected CC will involve an additional threat for their sustainability. Appropriate strategies and adaptation measures should be effectively transferred and implemented in the sector according to their regional context, so the main risks of CC could be partially mitigated. Furthermore, under an integrated policy framework, bridging Rural development, Climate, and Research \& Innovation aspects, such measures could promote those specific features and services of small 
ruminants systems that provide them competitive advantages (at animal and system level) against other livestock systems, thus enhancing their role -and future sustainability- in the face of a changing climate.

\section{Acknowledgements}

This research is supported by the Spanish Government through María de Maeztu excellence accreditation 2018-2022 (Ref. MDM-2017-0714) and by the Basque Government through the BERC 2018-2021 programme. This work was also supported by the Horizon2020 SFS-01c-2015 project entitled "Innovation of sustainable sheep and goat production in Europe (iSAGE)" (grant number 679302). Agustin del Prado is financed by the programme Ramon y Cajal from the Spanish Ministry of Economy, Industry and Competitiveness (RYC-2017-22143).

\section{Declaration of interest}

The authors declare they have no conflicts of interest.

\section{References}

Ainsworth, E.A., Long, S.P., 2005. What have we learned from 15 years of free-air CO2 enrichment (FACE)? A meta-analytic review of the responses of photosynthesis, canopy properties and plant production to rising $\mathrm{CO}$. New Phytologist 165, 351-372. https://doi.org/10.1111/j.1469-8137.2004.01224.x

Albenzio, M., Marino, R., Caroprese, M., Santillo, A., Annicchiarico, G., Sevi, A., 2004. Quality of milk and of Canestrato Pugliese cheese from ewes exposed to 
different ventilation regimens. Journal of Dairy Research 71, 434-443. https://doi.org/10.1017/S0022029904000330

Al-Dawood, A., 2017. Towards Heat Stress Management in Small Ruminants - A Review. Annals of Animal Science 17, 59-88. https://doi.org/10.1515/aoas$\underline{2016-0068}$

Allard, V., Newton, P.C.D., Lieffering, M., Clark, H., Matthew, C., Soussana, J.-F., Gray, Y.S., 2003. Nitrogen cycling in grazed pastures at elevated CO2: N returns by ruminants. Global Change Biology 9, 1731-1742. https://doi.org/10.1111/j.1365-2486.2003.00711.x

Alonso-Ayuso, M., Gabriel, J.L., Quemada, M., 2014. The Kill Date as a Management Tool for Cover Cropping Success. PLOS ONE 9, e109587. https://doi.org/10.1371/journal.pone.0109587

Alvarez, L., Guevara, N., Reyes, M., Sánchez, A., Galindo, F., 2013. Shade effects on feeding behavior, feed intake, and daily gain of weight in female goat kids. Journal of Veterinary Behavior 8, 466-470. https://doi.org/10.1016/j.jveb.2013.08.002

Bale, J.S., Masters, G.J., Hodkinson, I.D., Awmack, C., Bezemer, T.M., Brown, V.K., Butterfield, J., Buse, A., Coulson, J.C., Farrar, J., Good, J.E.G., Harrington, R., Hartley, S., Jones, T.H., Lindroth, R.L., Press, M.C., Symrnioudis, I., Watt, A.D., Whittaker, J.B., 2002. Herbivory in global climate change research: direct effects of rising temperature on insect herbivores. Global Change Biology 8, 116. https://doi.org/10.1046/j.1365-2486.2002.00451.x

Brophy, C., Finn, J.A., Lüscher, A., Suter, M., Kirwan, L., Sebastià, M.-T., Helgadóttir, Á., Baadshaug, O.H., Bélanger, G., Black, A., Collins, R.P., Čop, J., Dalmannsdottir, S., Delgado, I., Elgersma, A., Fothergill, M., Frankow- 
Lindberg, B.E., Ghesquiere, A., Golinska, B., Golinski, P., Grieu, P., Gustavsson, A.-M., Höglind, M., Huguenin-Elie, O., Jørgensen, M., Kadziuliene, Z., Kurki, P., Llurba, R., Lunnan, T., Porqueddu, C., Thumm, U., Connolly, J., 2017. Major shifts in species' relative abundance in grassland mixtures alongside positive effects of species diversity in yield: a continental-scale experiment. Journal of Ecology 105, 1210-1222. https://doi.org/10.1111/1365$\underline{2745.12754}$

Brown, D.L., Morrison, S.R., Bradford, G.E., 1988. Effects of Ambient Temperature on Milk Production of Nubian and Alpine Goats. Journal of Dairy Science 71, 2486-2490. https://doi.org/10.3168/jds.S0022-0302(88)79835-5

Bureau, J.-C., Swinnen, J., 2018. EU policies and global food security. Global Food Security 16, 106-115. https://doi.org/10.1016/i.gfs.2017.12.001

Caminade, C., Mclntyre, K.M., Jones, A.E., 2019. Impact of recent and future climate change on vector-borne diseases. Ann N Y Acad Sci 1436, 157-173. https://doi.org/10.1111/nyas.13950

Carabaño, M.J., Ramón, M., Díaz, C., Molina, A., Pérez-Guzmán, M.D., Serradilla, J.M., 2017. BREEDING AND GENETICS SYMPOSIUM: Breeding for resilience to heat stress effects in dairy ruminants. A comprehensive review. J Anim Sci 95, 1813-1826. https://doi.org/10.2527/jas.2016.1114

Caroprese, M., Albenzio, M., Bruno, A., G.Annicchiarico, Marino, R., Sevi, A., 2012. Effects of shade and flaxseed supplementation on the welfare of lactating ewes under high ambient temperatures. Small Ruminant Research 102, 177-185. https://doi.org/10.1016/j.smallrumres.2011.07.010 
Charlier, J., van der Voort, M., Kenyon, F., Skuce, P., Vercruysse, J., 2014. Chasing helminths and their economic impact on farmed ruminants. Trends in Parasitology 30, 361-367. https://doi.org/10.1016/j.pt.2014.04.009

Chauhan, S.S., Celi, P., Leury, B.J., Clarke, I.J., Dunshea, F.R., 2014. Dietary antioxidants at supranutritional doses improve oxidative status and reduce the negative effects of heat stress in sheep,. J Anim Sci 92, 3364-3374. https://doi.org/10.2527/jas.2014-7714

Cotrufo, M.F., Ineson, P., Scott, A., 1998. Elevated CO2 reduces the nitrogen concentration of plant tissues. Global Change Biology 4, 43-54. https://doi.org/10.1046/j.1365-2486.1998.00101.x

D'Alexis, S., Sauvant, D., Boval, M., 2014. Mixed grazing systems of sheep and cattle to improve liveweight gain: a quantitative review. The Journal of $\begin{array}{llll}\text { Agricultural } & \text { Science } & \text { 655-666. }\end{array}$ https://doi.org/10.1017/S0021859613000622

Darcan, N., Cankaya, S., 2008. The effects of ventilation and showering on fattening performances and carcass traits of crossbred kids. Small Ruminant Research 75, 192-198. https://doi.org/10.1016/i.smallrumres.2007.10.004

Darcan, N., Güney, O., 2008. Alleviation of climatic stress of dairy goats in Mediterranean climate. Small Ruminant Research 74, 212-215. https://doi.org/10.1016/j.smallrumres.2007.02.007

Dellar, M., Topp, C.F.E., Banos, G., Wall, E., 2018. A meta-analysis on the effects of climate change on the yield and quality of European pastures. Agriculture,

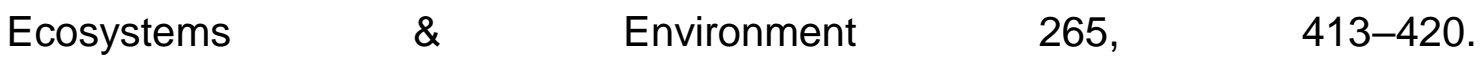
https://doi.org/10.1016/..agee.2018.06.029 
Devine, C.E., Graafhuis, A.E., Muir, P.D., Chrystall, B.B., 1993. The effect of growth rate and ultimate $\mathrm{pH}$ on meat quality of lambs. Meat Science 35, 63-77. https://doi.org/10.1016/0309-1740(93)90070-X

Dumont, B., Andueza, D., Niderkorn, V., Lüscher, A., Porqueddu, C., Picon-Cochard, C., 2015. A meta-analysis of climate change effects on forage quality in grasslands: specificities of mountain and Mediterranean areas. Grass and Forage Science 70, 239-254. https://doi.org/10.1111/gfs.12169

Dumont, B., Carrère, P., Ginane, C., Farruggia, A., Lanore, L., Tardif, A., Decuq, F., Darsonville, O., Louault, F., 2011. Plant-herbivore interactions affect the initial direction of community changes in an ecosystem manipulation experiment. Basic and Applied Ecology 12, 187-194. https://doi.org/10.1016/i.baae.2011.02.011

Durmus, M., Agossou, D.J, Koluman, N., 2019. Sustainability of Small Ruminant Production in Mediterranean Region. JESE-B 8. https://doi.org/10.17265/2162$5263 / 2019.06 .005$

Escarcha, J.F., Lassa, J.A., Zander, K.K., 2018. Livestock Under Climate Change: A Systematic Review of Impacts and Adaptation. Climate 6, 54. https://doi.org/10.3390/cli6030054

Forcada, F., Abecia, J.-A., 2006. The effect of nutrition on the seasonality of reproduction in ewes. Reprod. Nutr. Dev. 46, 355-365. https://doi.org/10.1051/rnd:2006017

Fuhrer, J., 2009. Ozone risk for crops and pastures in present and future climates. Naturwissenschaften 96, 173-194. https://doi.org/10.1007/s00114-008-0468-7

Gonzalez-Rivas, P.A., DiGiacomo, K., Russo, V.M., Leury, B.J., Cottrell, J.J., Dunshea, F.R., 2016. Feeding slowly fermentable grains has the potential to 
ameliorate heat stress in grain-fed wethers,. J Anim Sci 94, 2981-2991. https://doi.org/10.2527/jas.2016-0295

Hamzaoui, S., Salama, A.A.K., Albanell, E., Such, X., Caja, G., 2013a. Physiological responses and lactational performances of late-lactation dairy goats under heat stress conditions. Journal of Dairy Science 96, 6355-6365. https://doi.org/10.3168/jds.2013-6665

Hamzaoui, S., Salama, A.A.K., Caja, G., Albanell, E., Flores, C., Such, X., 2013b. Milk production losses in early lactating dairy goats under heat stress. Journal of Dairy Science 95, 672-673.

Henry, B.K., Eckard, R.J., Beauchemin, K.A., 2018. Review: Adaptation of ruminant livestock production systems to climate changes. animal 12, s445-s456. https://doi.org/10.1017/S1751731118001301

Hofer, D., Suter, M., Haughey, E., Finn, J.A., Hoekstra, N.J., Buchmann, N., Lüscher, A., 2016. Yield of temperate forage grassland species is either largely resistant or resilient to experimental summer drought. Journal of Applied Ecology 53, 1023-1034. https://doi.org/10.1111/1365-2664.12694

Höglind, M., Thorsen, S.M., Semenov, M.A., 2013. Assessing uncertainties in impact of climate change on grass production in Northern Europe using ensembles of global climate models. Agricultural and Forest Meteorology, Agricultural prediction using climate model ensembles 170, 103-113. https://doi.org/10.1016/j.agrformet.2012.02.010

Hopkins, A., Prado, A.D., 2007. Implications of climate change for grassland in Europe: impacts, adaptations and mitigation options: a review. Grass and Forage Science 62, 118-126. $\quad$ https://doi.org/10.1111/j.1365$\underline{2494.2007 .00575 . x}$ 
Howieson, J.G., O'Hara, G.W., Carr, S.J., 2000. Changing roles for legumes in Mediterranean agriculture: developments from an Australian perspective. Field Crops Research 65, 107-122. https://doi.org/10.1016/S0378-4290(99)00081-7 Jacob, D., Petersen, J., Eggert, B., Alias, A., Christensen, O.B., Bouwer, L.M., Braun, A., Colette, A., Déqué, M., Georgievski, G., Georgopoulou, E., Gobiet, A., Menut, L., Nikulin, G., Haensler, A., Hempelmann, N., Jones, C., Keuler, K., Kovats, S., Kröner, N., Kotlarski, S., Kriegsmann, A., Martin, E., Meijgaard, E. van, Moseley, C., Pfeifer, S., Preuschmann, S., Radermacher, C., Radtke, K., Rechid, D., Rounsevell, M., Samuelsson, P., Somot, S., Soussana, J.-F., Teichmann, C., Valentini, R., Vautard, R., Weber, B., Yiou, P., 2014. EUROCORDEX: new high-resolution climate change projections for European impact research. Reg Environ Change 14, 563-578. https://doi.org/10.1007/s10113$\underline{013-0499-2}$

Jáuregui, B.M., García, U., Osoro, K., Celaya, R., 2009. Sheep and Goat Grazing Effects on Three Atlantic Heathland Types. Rangeland Ecology \& Management 62, 119-126. https://doi.org/10.2111/07-120.1

Joy, A., Dunshea, F.R., Leury, B.J., Clarke, I.J., DiGiacomo, K., Chauhan, S.S., 2020. Resilience of Small Ruminants to Climate Change and Increased Environmental Temperature: A Review. Animals 10, 867. https://doi.org/10.3390/ani10050867

Kirwan, L., Lüscher, A., Sebastià, M.T., Finn, J.A., Collins, R.P., Porqueddu, C., Helgadottir, A., Baadshaug, O.H., Brophy, C., Coran, C., Dalmannsdóttir, S., Delgado, I., Elgersma, A., Fothergill, M., Frankow-Lindberg, B.E., Golinski, P., Grieu, P., Gustavsson, A.M., Höglind, M., Huguenin-Elie, O., Iliadis, C., Jørgensen, M., Kadziuliene, Z., Karyotis, T., Lunnan, T., Malengier, M., Maltoni, 
S., Meyer, V., Nyfeler, D., Nykanen-Kurki, P., Parente, J., Smit, H.J., Thumm, U., Connolly, J., 2007. Evenness drives consistent diversity effects in intensive grassland systems across 28 European sites. Journal of Ecology 95, 530-539. https://doi.org/10.1111/j.1365-2745.2007.01225.x

Kukovics, S., 2016. Sustainable goat breeding and goat farming in the Central and Eastern European countries. Presented at the Sustainable Goat Breeding and Goat Farming in the Central and Eastern European Countries Debrecen (Hungary) 7-13 Apr 2014, FAO.

Lee, J.M., Clark, A.J., Roche, J.R., 2013. Climate-change effects and adaptation options for temperate pasture-based dairy farming systems: a review. Grass and Forage Science 68, 485-503. https://doi.org/10.1111/gfs.12039

Loka, D., Humphreys, M., Gwyn Jones, D., Scullion, J., Doonan, J., Gasior, D., Harper, J., Farrell, M., Kingston-Smith, A., Dodd, R., Chadwick, D., Hill, P., Robinson, D., Jones, D., 2016. Designing Resilient and Productive Grasses with Plasticity to Extreme Weather Events. AGU Fall Meeting Abstracts 53.

Lu, C.D., 1989. Effects of heat stress on goat production. Small Ruminant Research 2, 151-162. https://doi.org/10.1016/0921-4488(89)90040-0

Lüscher, A., Mueller-Harvey, I., Soussana, J.F., Rees, R.M., Peyraud, J.L., 2014. Potential of legume-based grassland-livestock systems in Europe: a review. Grass and Forage Science 69, 206-228. https://doi.org/10.1111/gfs.12124

Luske, B., Eekeren, N. van, 2015. Potential of fodder trees in high-output dairy systems. Grassland and forages in high output dairy farming systems. Proceedings of the 18th Symposium of the European Grassland Federation, Wageningen, The Netherlands, 15-17 June 2015 250-252. 
Mahjoubi, E., Amanlou, H., Mirzaei-Alamouti, H.R., Aghaziarati, N., Yazdi, M.H., Noori, G.R., Yuan, K., Baumgard, L.H., 2014. The effect of cyclical and mild heat stress on productivity and metabolism in Afshari lambs. J Anim Sci 92, 1007-1014. https://doi.org/10.2527/jas.2013-7153

Mancilla-Leytón, J.M., Mejías, R.P., Vicente, A.M., 2013. Do goats preserve the forest? Evaluating the effects of grazing goats on combustible Mediterranean scrub. Applied Vegetation Science 16, 63-73. https://doi.org/10.1111/j.1654$\underline{109 X .2012 .01214 . x}$

Marai, I.F.M., El-Darawany, A.A., Fadiel, A., Abdel-Hafez, M.A.M., 2007. Physiological traits as affected by heat stress in sheep-A review. Small $\begin{array}{llr}\text { Ruminant } & \text { Research } & \text { 1-12. }\end{array}$ https://doi.org/10.1016/j.smallrumres.2006.10.003

Marino, R., Atzori, A.S., D’Andrea, M., lovane, G., Trabalza-Marinucci, M., Rinaldi, L., 2016. Climate change: Production performance, health issues, greenhouse gas emissions and mitigation strategies in sheep and goat farming. Small Ruminant Research, Special Issue: Advances in Sheep and Goats Research: A Holistic Approach. Selected papers from SIPAOC 2014 Meeting, Italy 135, 50_ 59. https://doi.org/10.1016/j.smallrumres.2015.12.012

Martin, R., Müller, B., Linstädter, A., Frank, K., 2014. How much climate change can pastoral livelihoods tolerate? Modelling rangeland use and evaluating risk. Global Environmental Change 24, 183-192. https://doi.org/10.1016/i.gloenvcha.2013.09.009

Morand-Fehr, P., Boyazoglu, J., 1999. Present state and future outlook of the small ruminant sector. Small Ruminant Research 34, 175-188. https://doi.org/10.1016/S0921-4488(99)00071-1 
Morgan, E.R., Aziz, N.-A.A., Blanchard, A., Charlier, J., Charvet, C., Claerebout, E., Geldhof, P., Greer, A.W., Hertzberg, H., Hodgkinson, J., Höglund, J., Hoste, H., Kaplan, R.M., Martínez-Valladares, M., Mitchell, S., Ploeger, H.W., Rinaldi, L., von Samson-Himmelstjerna, G., Sotiraki, S., Schnyder, M., Skuce, P., Bartley, D., Kenyon, F., Thamsborg, S.M., Vineer, H.R., de Waal, T., Williams, A.R., van Wyk, J.A., Vercruysse, J., 2019. 100 Questions in Livestock Helminthology $\begin{array}{llll}\text { Research. } \quad \text { Trends } & \text { 52-71. }\end{array}$ https://doi.org/10.1016/j.pt.2018.10.006

Mottet, A., de Haan, C., Falcucci, A., Tempio, G., Opio, C., Gerber, P., 2017. Livestock: On our plates or eating at our table? A new analysis of the feed/food debate. Global Food Security, Food Security Governance in Latin America 14, 1-8. https://doi.org/10.1016/j.gfs.2017.01.001

Newton, P.C.D., Lieffering, M., Parsons, A.J., Brock, S.C., Theobald, P.W., Hunt, C.L., Luo, D., Hovenden, M.J., 2014. Selective grazing modifies previously anticipated responses of plant community composition to elevated $\mathrm{CO} 2$ in a temperate grassland. Global Change Biology 20, 158-169. https://doi.org/10.1111/gcb.12301

Niderkorn, V., Martin, C., Rochette, Y., Julien, S., Baumont, R., 2015. Associative effects between orchardgrass and red clover silages on voluntary intake and digestion in sheep: Evidence of a synergy on digestible dry matter intake. $J$ Anim Sci 93, 4967-4976. https://doi.org/10.2527/jas.2015-9178

Nowak, R.S., Ellsworth, D.S., Smith, S.D., 2004. Functional responses of plants to elevated atmospheric CO2- do photosynthetic and productivity data from FACE experiments support early predictions? New Phytologist 162, 253-280. https://doi.org/10.1111/j.1469-8137.2004.01033.x 
Obermeier, W.A., Lehnert, L.W., Kammann, C.I., Müller, C., Grünhage, L., Luterbacher, J., Erbs, M., Moser, G., Seibert, R., Yuan, N., Bendix, J., 2017. Reduced CO 2 fertilization effect in temperate C3 grasslands under more extreme weather conditions. Nature Climate Change 7, 137-141. https://doi.org/10.1038/nclimate3191

Pennisi, P., Costa, A., Biondi, L., Avondo, M., Piccione, G., 2004. Influence of the fleece on thermal homeostasis and on body condition in Comisana ewe lambs. Anim. Res. 53, 13-19. https://doi.org/10.1051/animres:2003047

Provenza, F.D., Villalba, J.J., Dziba, L.E., Atwood, S.B., Banner, R.E., 2003. Linking herbivore experience, varied diets, and plant biochemical diversity. Small Ruminant Research, Advanced research on nutrition of sheep and goats, with special reference to pasture and rangeland use 49, 257-274. https://doi.org/10.1016/S0921-4488(03)00143-3

Romo-Barron, C.B., Diaz, D., Portillo-Loera, J.J., Romo-Rubio, J.A., Jimenez-Trejo, F., Montero-Pardo, A., 2019. Impact of heat stress on the reproductive performance and physiology of ewes: a systematic review and meta-analyses. Int J Biometeorol 63, 949-962. https://doi.org/10.1007/s00484-019-01707-z

Salama, A.A.K., Caja, G., Hamzaoui, S., Badaoui, B., Castro-Costa, A., Façanha, D.A.E., Guilhermino, M.M., Bozzi, R., 2014. Different levels of response to heat stress in dairy goats. Small Ruminant Research, Special Issue: Industrial and Rural Activities in the Goat Sector including Science, Innovation and Development 121, 73-79. https://doi.org/10.1016/i.smallrumres.2013.11.021

Salami, S.A., Luciano, G., O’Grady, M.N., Biondi, L., Newbold, C.J., Kerry, J.P., Priolo, A., 2019. Sustainability of feeding plant by-products: A review of the 
implications for ruminant meat production. Animal Feed Science and Technology 251, 37-55. https://doi.org/10.1016/j.anifeedsci.2019.02.006

Sargison, N.D., 2016. Keys to solving health problems in small ruminants: Anthelmintic resistance as a threat to sustainable nematode control. Small Ruminant Research, Special Issue: Keynote Lectures of The XL National congress and XVI International of The Spanish Society for Sheep and Goat Production (S.E.O.C.) 142, 11-15. https://doi.org/10.1016/..smallrumres

Sevi, A., Caroprese, M., 2012. Impact of heat stress on milk production, immunity and udder health in sheep: A critical review. Small Ruminant Research 107, 17. https://doi.org/10.1016/j.smallrumres.2012.07.012

Sharrow, S.H. (Oregon S.U., Leininger, W.C., Rhodes, B., 1989. Sheep grazing as a silvicultural tool to suppress brush. Journal of range management (USA).

Silanikove, N., Koluman (Darcan), N., 2015. Impact of climate change on the dairy industry in temperate zones: Predications on the overall negative impact and on the positive role of dairy goats in adaptation to earth warming. Small Ruminant Research 123, 27-34. https://doi.org/10.1016/j.smallrumres.2014.11.005

Sitzia, M., Bonanno, A., Todaro, M., Cannas, A., Atzori, A.S., Francesconi, A.H.D., Trabalza-Marinucci, M., 2015. Feeding and management techniques to favour summer sheep milk and cheese production in the Mediterranean environment. Small Ruminant Research, Supplement: S.I.P.A.O.C. Congress 2012 126, 4358. https://doi.org/10.1016/j.smallrumres.2015.01.021

Sotiraki, S., Stefanakis, A., Hoste, H., Maurer, V., Butler, G., Leifert, C., 2013. The role of biotic and abiotic stress factors on sheep welfare: the example of parasites and climatic changes in European countries. Options Méditerranéennes. Série A, Séminaires Méditerranéens 159-169. 
Van Dijk, J., Sargison, N.D., Kenyon, F., Skuce, P.J., 2010. Climate change and infectious disease: helminthological challenges to farmed ruminants in $\begin{array}{llll}\text { temperate } & \text { regions. } & \text { animal } & \text { 377-392. }\end{array}$ https://doi.org/10.1017/S1751731109990991

Van Soest, P.J., 1982. Nutritional ecology of the ruminant. O \& B Books. Inc., Corvallis, OR 374.

Volaire, F., Barkaoui, K., Norton, M., 2014. Designing resilient and sustainable grasslands for a drier future: Adaptive strategies, functional traits and biotic interactions. European Journal of Agronomy 52, 81-89. https://doi.org/10.1016/j.eja.2013.10.002 


\section{Supplementary Material S1:}

Literature search methodology:

Available literature about small ruminants under heat stress was searched and a selection of studies was conducted based on the following criteria: 1) the trials involved sheep or goats, 2) they analysed performance under thermoneutral (TN) and heat stress (HS) conditions, and 3) the studies provided information at least on one of these parameters: respiration rate $(R R)$, rectal temperature $(R T)$, feed intake (FI), milk production (lactating animals). The collected studies that met the previous criteria were further filtered, so the trials involving breeds from tropical regions (e.g. India, Brazil) were excluded. The meteorological data provided in the collected studies were converted into THI based on Marai et al., 2007 and Kelly et al., 1971. After the literature search, a total of 17 studies (involving 32 trials) monitoring ambient conditions and animal-based indicators related to signs of HS (respiration rate and/or rectal temperature) were selected. Details of the studies collected according to these criteria can be checked in Supplementary Table S1.

For feed intake, 13 datasets were identified, involving 7 studies of dairy systems and 6 from meat systems. Details of the studies collected according to these criteria can be checked in Supplementary Table S2.

Finally, datasets from 12 studies reporting decline of milk production (and/or composition) were selected. The milk loss reported in those studies was converted into fat and protein correct milk (FPCM) according to Pulina, Macciotta and Nuda (2004) in order to normalise the results. Details of the studies selected are described in Supplementary Table S3. 
Table S1 - Selection of reviewed studies reporting respiration rate $(R R)$ and/or rectal temperature (RT) for dairy sheep and goats under heat stress.

\begin{tabular}{|c|c|c|c|c|c|c|}
\hline \multirow[t]{2}{*}{ Reference } & \multirow[t]{2}{*}{ Species } & \multirow[t]{2}{*}{ System } & \multirow{2}{*}{\multicolumn{2}{|c|}{ Breed }} & \multirow[b]{2}{*}{$\begin{array}{l}\text { RR } \\
\text { (breaths/min) }\end{array}$} & \multirow[b]{2}{*}{$\begin{array}{l}\mathrm{RT} \\
\left({ }^{\circ} \mathrm{C}\right)\end{array}$} \\
\hline & & & & & & \\
\hline Abdalla et al., 1993 & Sheep & Dairy & DorsetxRambouillet & $19-32$ & $72-149$ & $39.1-40.1$ \\
\hline Bernabucci 2009 & Sheep & Dairy & Sardinian & $19-30$ & $47-125$ & $39.3-39.8$ \\
\hline Brasil et al., 2000 & Goat & Dairy & Alpine & $22-32$ & $38-127$ & $39.1-40.0$ \\
\hline Hamzaoui 2014 & Goat & Dairy & Murciano-Granadina & $19-33$ & $34-136$ & $38.7-40.2$ \\
\hline Hamzaoui et al., 2013 & Goat & Dairy & Murciano-Granadina & $19-33$ & $45-110$ & $38.9-39.6$ \\
\hline Alhidary et al., 2012 & Sheep & Meat & Merino & $23-34$ & $39-110$ & $39.1-39.8$ \\
\hline Bhattacharya 1974 & Sheep & Meat & Awassi & $19-31$ & $31-101$ & $39.1-39.3$ \\
\hline da Silva et al., 1992 & Sheep & Meat & Polwarth & $20-32$ & - & $38.7-39.8$ \\
\hline Denek et al., 2006 & Sheep & Meat & Awassi & $11-27$ & - & $39.0-39.7$ \\
\hline Dixon et al., 1999 & Sheep & Meat & Merino & $15-36$ & $49-208$ & $39.2-40.2$ \\
\hline Faichney 1986 & Sheep & Meat & Corriedale & $21-28$ & $18-82$ & $38.9-39.0$ \\
\hline Lees et al., 2017 & Sheep & Meat & Merino & $23-36$ & $51-222$ & - \\
\hline Mahjoubi et al., 2014 & Sheep & Meat & Afshari & $24-33$ & $84-188$ & $39.5-40.1$ \\
\hline Mittal et al., 1979 & Sheep & Meat & Corriedale & $26-34$ & $45-110$ & $38.7-40.7$ \\
\hline Monty et al., 1991 & Sheep & Meat & St. Croix/Rambouillet & $21-34$ & $32-170$ & $38.7-40.7$ \\
\hline Srikandakumar et al., 2003 & Sheep & Meat & Merino & $22-35$ & $50-128$ & $39.5-39.8$ \\
\hline Wojtas et al., 2014 & Sheep & Meat & Merino & $20-28$ & $56-96$ & $39.4-39.4$ \\
\hline
\end{tabular}

Table S2 - Selection of reviewed studies reporting feed intake (FI) decrease (\%) for sheep and goats under heat stress.

\begin{tabular}{lllll}
\hline Reference & System & Breed & THI range & Fl loss (\%) \\
\hline Abdalla et al., 1993 & Dairy sheep & Dorset x Rambouillet & $19-32$ & $29 \%$ \\
Alhidary et al., 2012 & Meat sheep & Merino & $22-32$ & $23 \%$ \\
Ames and Brink 1977 & Meat sheep & Merino & $19-32$ & $4-35 \%$ \\
Bhattacharya et al., 1974 & Meat sheep & Awassi & $19-33$ & $4 \%$ \\
Bernabucci et al., 2009 & Dairy sheep & Sardinian & $19-30$ & $4 \%$ \\
Brasil et al., 2000 & Dairy goats & Alpine & $22-32$ & $8 \%$ \\
Brown et al., 1988 & Dairy goats & Alpine & $19-29$ & $6 \%$ \\
Denek et al., 2006 & Meat sheep & Awassi & $11-27$ & $2-17 \%$ \\
Dixon et al., 1999 & Meat sheep & Merino & $15-34$ & $7-12 \%$ \\
Hamzaoui et al., 2014 & Dairy goats & Murciano-granadina & $19-33$ & $29-35 \%$ \\
Hamzaoui et al., 2013 & Dairy goats & Murciano-granadina & $19-33$ & $21 \%$ \\
Leibovich et al., 2011 & Dairy sheep & Assaf & $26-29$ & $10 \%$ \\
Sano et al., 1985 & Dairy goats & Saanen & $19-33$ & $4-18 \%$ \\
\hline
\end{tabular}


Table S3 - Selection of reviewed studies reporting milk yield decline (\%) for sheep and goats under heat stress. The results have been converted into fat and protein correct milk (FPCM) according to Pulina, Macciotta and Nuda (2004)

\begin{tabular}{lllll}
\hline Reference & System & Breed & THI range & $\begin{array}{l}\text { FPCM loss } \\
(\%)\end{array}$ \\
\hline Abdalla et al., 1993 & Dairy sheep & Dorset x Rambouillet & $19-32$ & $27 \%$ \\
Brasil et al., 2000 & Dairy goats & Alpine & $22-32$ & $8 \%$ \\
Brown et al., 1988 & Dairy goats & Alpine & $19-29$ & $8-20 \%$ \\
Finocchiaro et al., 2005 & Dairy sheep & Sarda & $19-32$ & $31 \%$ \\
Hamzaoui et al., 2014 & Dairy goats & Murciano-granadina & $19-33$ & $11-16 \%$ \\
Hamzaoui et al., 2013 & Dairy goats & Murciano-granadina & $19-33$ & $5 \%$ \\
Leibovich et al., 2011 & Dairy sheep & Assaf & $26-29$ & $12 \%$ \\
Menéndez-Buxadera et & Dairy goats & Murciano- & $21-32$ & $9-29 \%$ \\
al., 2013 & & granadina/Payoya & & \\
Menéndez-Buxadera et & Dairy goats & Murciano- & $21-32$ & $7-8 \%$ \\
al., 2012 & & granadina/Payoya & $20-32$ & $19 \%$ \\
Peana et al., 2007 & Dairy sheep & Sarda & $22-30$ & $1 \%$ \\
Ramón et al., 2015 & Dairy sheep & Manchega & $19-33$ & $13 \%$ \\
Romero et al., 2008 & Dairy goat & Payoya & & \\
\hline
\end{tabular}




\section{Supplementary Figures:}

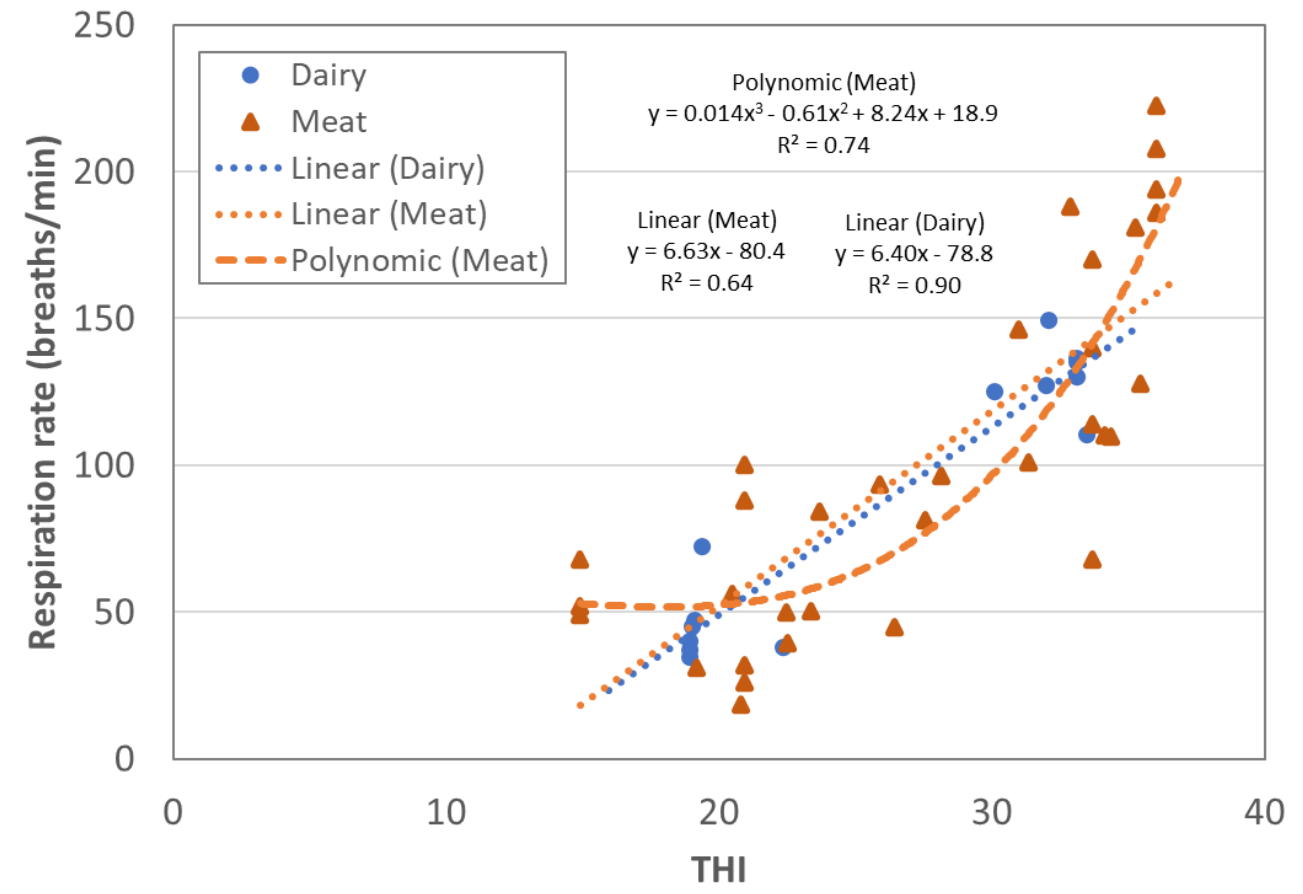

Figure S1 - Relationships between respiration rate and THI of reviewed studies on small ruminants under heat stress from dairy and meat systems

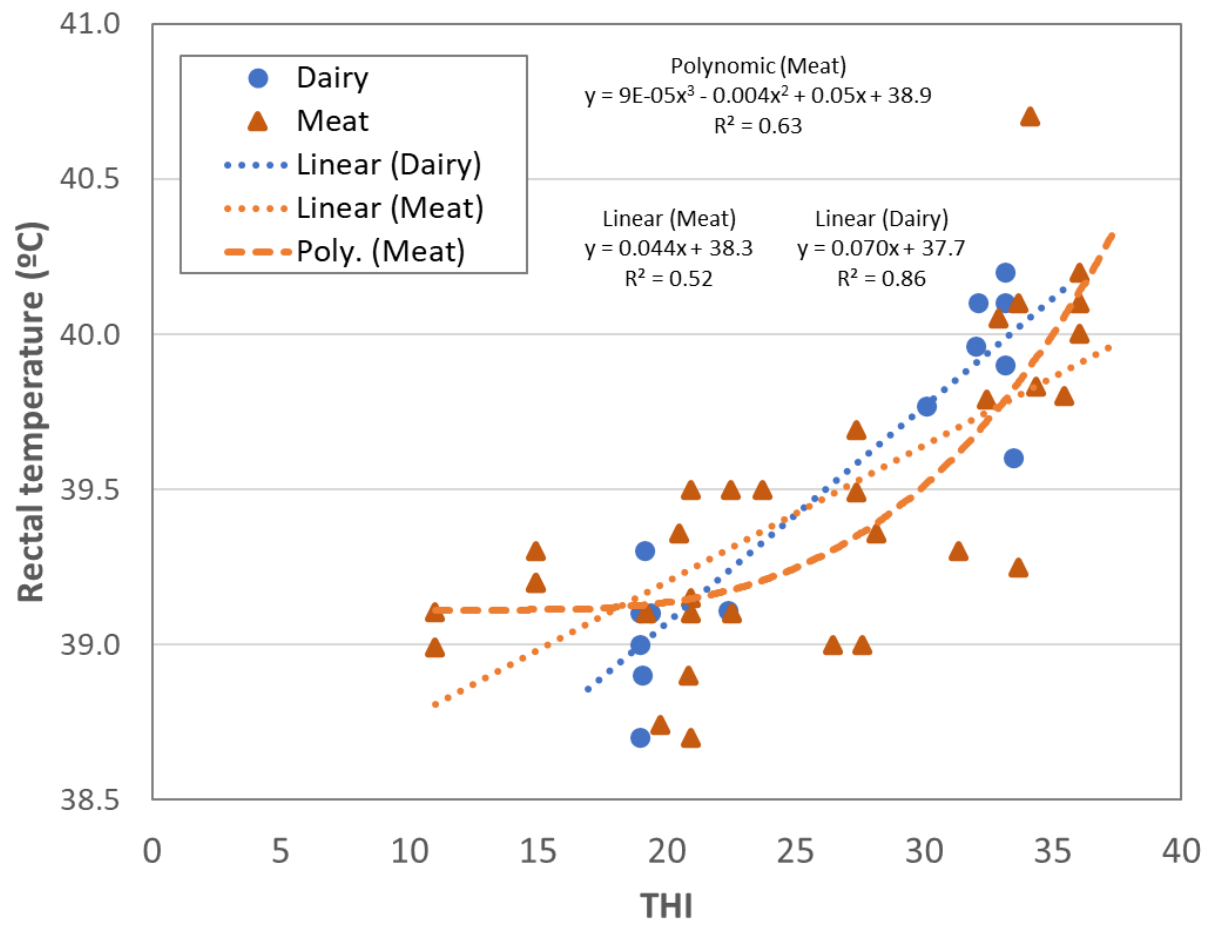

Figure S2. Relationships between rectal temperature and THI of reviewed studies on small ruminants under heat stress from dairy and meat systems 


\section{References Supplementary Material S1:}

Abdalla EB, Kotby EA and Johnson HD 1993. Physiological responses to heatinduced hyperthermia of pregnant and lactating ewes. Small Ruminant Research 11, 125-134.

Alhidary IA, Shini S, Al Jassim RAM and Gaughan JB 2012. Physiological responses of australian merino wethers exposed to high heat load. Journal of Animal Science 90, 212-220.

Ames DR and Brink DR 1977. Effect of temperature on lamb performance and protein efficiency ratio. Journal of animal science 44, 136-144.

Bernabucci U, Lacetera N, Danieli PP, Bani P, Nardone A and Ronchi B 2009. Influence of different periods of exposure to hot environment on rumen function and diet digestibility in sheep. International Journal of Biometeorology 53, 387395.

Bhattacharya AN and Hussain F 1974. Intake and utilization of nutrients in sheep fed different levels of roughage under heat stress. Journal of Animal Science 38, 877-886.

Brasil LH de A, Wechesler FS, Baccari Júnior F, Gonçalves HC and Bonassi IA 2000. Efeitos do estresse térmico sobre a produção, composição química do leite e respostas termorreguladoras de cabras da raça alpina. Revista Brasileira de Zootecnia 29, 1632-1641.

Brown, LD, Morrison SR and Bradford GE 1988. Effects of ambient temperature on milk production of Nubian and Alpine goats. Journal of Dairy Science 71, 24862490.

Denek N, Can A, Tufenk S, Yazgan K, Ipek H and Iriadam M 2006. The effect of heat load on nutrient utilization and blood parameters of Awassi ram lambs fed different types and levels of forages. Small Ruminant Research 63, 156-161.

da Silva RG, da Costa MJRP and Sobrinho AGS 1992. Influence of hot environments on some blood variables of sheep. International journal of biometeorology 36, 223-225.

Dixon RM, Thomas R and Holmes JHG 1999. Interactions between heat stress and nutrition in sheep fed roughage diets. The Journal of Agricultural Science 132, 351-359. 
Faichney GJ and Barry TN 1986. Effects of mild heat exposure and suppression of prolactin secretion on gastro-intestinal tract function and temperature regulation in sheep. Australian Journal of Biological Sciences 39, 85-97.

Finocchiaro R, van Kaam JBCHM, Portolano B and Misztal I 2005. Effect of heat stress on production of Mediterranean dairy sheep. Journal of Dairy Science 88, 1855-1864.

Hamzaoui S, Salama AAK, Albanell E, Such X and Caja G 2013. Physiological responses and lactational performances of late-lactation dairy goats under heat stress conditions. Journal of Dairy Science 96, 6355-6365.

Hamzaoui S 2014. Heat stress responses in dairy goats and effects of some nutritional strategies for mitigation. PhD Thesis

Kelly CF, Bond TE, Yeck RG, McDowell RE, Dougherty RW, Hazen TE, Johnson HD, Johnston JE, Pace N and Smith SY 1971. A guide to environmental research on animals. Bioclimatic Factors and Their Measurement. National Academy of Sciences. Washington, De 42.

Lees AM, Sullivan ML, Cawdell-Smith AJ and Gaughan JB 2017. Developing heat stress thresholds for sheep. Journal of Animal Science 95, 246-247.

Leibovich H, Zenou A, Seada P and Miron J 2011. Effects of shearing, ambient cooling and feeding with byproducts as partial roughage replacement on milk yield and composition in Assaf sheep under heat-load conditions. Small Ruminant Research 99, 153-159.

Mahjoubi E, Amanlou H, Mirzaei-Alamouti HR, Aghaziarati N, Yazdi MH, Noori GR, Yuan K and Baumgard LH 2014. The effect of cyclical and mild heat stress on productivity and metabolism in Afshari lambs. Journal of animal science 92, 1007-1014.

Marai IFM, El-Darawany AA, Fadiel A and Abdel-Hafez MAM 2007. Physiological traits as affected by heat stress in sheep-A review. Small Ruminant Research 71, 1-12.

Menéndez-Buxadera A, Molina A, Arrebola F, Clemente I and Serradilla JM 2012. Genetic variation of adaptation to heat stress in two Spanish dairy goat breeds. Journal of Animal Breeding and Genetics 129, 306-315.

Menéndez-Buxadera A, Serradilla JM, Arrebola F, Clemente I, Castro JA, Osorio J, Torres R and Molina A 2013. Genetic variation for tolerance to heat stress in dairy small ruminants: Results obtained in Spain. In Options Méditerranéennes. 
Series A: Mediterranean Seminars (ed. International Centre for advanced Mediterranean Agronomic Studies), pp. 135-139. Tanger, Morocco.

Mittal JP and Ghosh PK 1979. Body temperature, respiration and pulse rate in Corriedale, Marwari and Magra sheep in the Rajasthan desert. The Journal of Agricultural Science 93, 587-591.

Monty DE, Kelley LM and Rice WR 1991. Acclimatization of St.-Croix, Karakul and Rambouillet sheep to intense and dry summer heat. Small Ruminant Research 4, 379-392.

Peana I, Fois G and Cannas A 2007. Effects of heat stress and diet on milk production and feed and energy intake of Sarda ewes. Italian Journal of Animal Science 6, 577-579.

Pulina G, Macciotta N and Nudda A 2005. Milk composition and feeding in the Italian dairy sheep. Italian Journal of Animal Science 4, 5-14.

Ramón M, Díaz C, Pérez-Guzman MD and Carabaño MJ 2016. Effect of exposure to adverse climatic conditions on production in Manchega dairy sheep. Journal of dairy science $99,5764-5779$.

Romero F, Molina A, González O, Clemente I, Arrebola F and Menéndez-Buxadera A 2008. Resultados preliminares del efecto de la temperatura y humedad relativa sobre la producción de leche y sus componentes en cabras de raza Payoya. ITEA Informacion Tecnica Economica Agraria 104, 243-248.

Sano H, Ambo K and Tsuda T 1985. Blood Glucose Kinetics in Whole Body and Mammary Gland of Lactating Goats Exposed to Heat. Journal of Dairy Science 68, 2557-2564.

Srikandakumar A, Johnson EH and Mahgoub O 2003. Effect of heat stress on respiratory rate, rectal temperature and blood chemistry in Omani and Australian Merino sheep. Small Ruminant Research 49, 193-198.

Wojtas K, Cwynar P and Kołacz R 2014. Effect of thermal stress on physiological and blood parameters in merino sheep. Bulletin of the Veterinary Institute in Pulawy 58, 283-288. 


\section{Supplementary Material 2:}

Literature search methodology:

Available literature about studies involving trials with small ruminants and agri-food by-products utilisation was searched. The data of the selected studies were extracted and are shown in Supplementary Table S4. Regional availability of organic by-products from agri-food industries in Europe was obtained following the methodology described in Pardo et al., 2017 from FAOSTAT data. 
Table S4 - Selection of reviewed studies involving utilisation of agri-food by-products in the diet of sheep and goats

\begin{tabular}{|c|c|c|c|c|c|}
\hline Reference & Basal diet & Alternative feed sources & Supplement type & Animal & Breed \\
\hline Abbeddou et al 2011 & Barley straw/concentrate & $\begin{array}{l}\text { Olive cake and leaves, } \\
\text { tomato pomace }\end{array}$ & - & Dairy ewes & Awassi \\
\hline Arco-Pérez et al 2017 & Alfalfa hay/concentrate & Olive cake, Tomato surplus & Silage & Dairy goats & Murciano-granadina \\
\hline Ben Salem and Znaidi 2008 & Wheat straw/concentrate & Tomato pulp, olive cake & Feed blocks & Lambs & Barbarine \\
\hline Bueno et al 2002 & Grass hay/concentrate & Citrus pulp & - & Kids & Saanen \\
\hline Cabbidu et al 2004 & Grass hay/concentrate & Olive cake & Silage & Dairy ewes & Sarda \\
\hline Caparra et al 2005 & Oat hay/concentrate & Citrus pulp & Dried & Lambs & Merino \\
\hline Chiofalo et al 2004 & Alfalfa hay/concentrate & Olive cake & - & dairy ewe & Comisana \\
\hline Denek and Can 2006 & Wheat straw/wheat grain & Tomato pomace & Silage & Rams & Awassi \\
\hline Di Francia et al 2004 & Oat hay/concentrate & Tomato pomace & Silage & dairy ewe & Comisana \\
\hline Eliyahu et al 2015 & Wheat hay/concentrate & $\begin{array}{l}\text { Pomegranate pulp, grape } \\
\text { pulp, avocado pulp }\end{array}$ & Silage & Lambs & Assaf \\
\hline Fegeros et al 1995 & Alfalfa hay/concentrate & Citrus pulp & Dried & Dairy ewe & Karagouniko \\
\hline Hadjipanayiotou et al 1999 & Barley straw/concentrate & Olive cake & Silage & Dairy ewes \& goats & Chios, Damascus \\
\hline Lanza et al 2001 & Wheat straw/barley+maize & Citrus pulp & - & Lambs & Barbaresca \\
\hline Molina-Alcaide et al 2010 & Alfalfa hay/concentrate & Olive cake & Feed blocks & Dairy goats & Murciano-granadina \\
\hline Nudda et al 2006 & Alfalfa hay/concentrate & Linseed cake & Extruded & Dairy goats & AlpinexSarda \\
\hline Pirmohammadi et al 2006 & - & Apple pomace & Silage, dried & Rams & Gezel \\
\hline Razzaghi et al 2015 & Alfalfa hay/concentrate & $\begin{array}{l}\text { Pomegranate seed pulp, } \\
\text { tomato pomace }\end{array}$ & - & Dairy goats & Saanen \\
\hline Romero-Huelva et al 2013 & Alfalfa hay/concentrate & $\begin{array}{l}\text { Tomato fruits, citrus pulp, } \\
\text { brewer's grain and yeast }\end{array}$ & - & Dairy goats & Murciano-granadina \\
\hline Romero-Huelva et al 2013 & Alfalfa hay/concentrate & $\begin{array}{l}\text { Tomato and cucumber fruit } \\
\text { wastes }\end{array}$ & Feed blocks & Dairy goats & Murciano-granadina \\
\hline
\end{tabular}




\begin{tabular}{llllll} 
Romero-Huelva et al 2017 & Alfalfa hay/concentrate & $\begin{array}{l}\text { Tomato fruits, citrus pulp, } \\
\text { brewer's grain and yeast }\end{array}$ & - & Dairy goats & Murciano-granadina \\
Scerra et al 2001 & Oat hay/concentrate & Citrus pulp & Silage & Lambs & Merinizzata \\
Sedighi-Vesagh et al 2014 & Alfalfa hay/concentrate & Pistachio by-products & - & Dairy goats & Saanen \\
Volanis et al 2004 & Oat hay/concentrate & Orange fruit waste & Silage & Dairy ewe & Sfakian \\
Volanis et al 2006 & Oat hay/concentrate & Citrus pulp & Silage & Dairy ewe & Sfakian \\
\hline
\end{tabular}




\section{References Supplementary Material S2:}

Abbeddou S, Rischkowsky B, Richter EK, Hess HD and Kreuzer M 2011. Modification of milk fatty acid composition by feeding forages and agroindustrial byproducts from dry areas to Awassi sheep. Journal of Dairy Science 94, 4657-4668.

Arco-Pérez A, Ramos-Morales E, Yáñez-Ruiz DR, Abecia L and Martín-García Al 2017. Nutritive evaluation and milk quality of including of tomato or olive byproducts silages with sunflower oil in the diet of dairy goats. Animal Feed Science and Technology 232, 57-70.

Bueno MS, Ferrari Jr E, Bianchini D, Leinz FF and Rodrigues CFC 2002. Effect of replacing corn with dehydrated citrus pulp in diets of growing kids. Small Ruminant Research 46, 179-185.

Cabiddu A, Canu M, Decandia M, Pompei R and Molle G 2004. The intake and performance of dairy ewes fed with different levels of olive cake silage in late pregnancy and suckling periods. Nutrition and feeding strategies of sheep and goats under harsh climates. Centre International de Hautes Études Agronomiques Méditerranéennes-Instituto Agronómico Mediterráneo de Zaragoza (CIHEAM-IAMZ), Zaragoza, Spain, 197-202.

Caparra P, Foti F, Scerra M, Sinatra MC and Scerra V 2007. Solar-dried citrus pulp as an alternative energy source in lamb diets: Effects on growth and carcass and meat quality. Small Ruminant Research 68, 303-311.

Chiofalo B, Liotta L, Zumbo A and Chiofalo V 2004. Administration of olive cake for ewe feeding: effect on milk yield and composition. Small Ruminant Research 55, 169-176.

Denek $\mathrm{N}$ and Can A 2006. Feeding value of wet tomato pomace ensiled with wheat straw and wheat grain for Awassi sheep. Small Ruminant Research 65, 260265.

Di Francia A, De Rosa G, Masucci F, Romano R and Grasso F 2004. Effetto dell'impiego alimentare del residuo industriale del passato di pomodoro sulle prestazioni produttive di pecore di razza Comisana. Proc. 16th Natl. Congr. SIPAOC, Siena, Italy, 271.

Eliyahu D, Shaani Y, Yosef E, Ben-Meir Y, Nikbachat M, Solomon R, Mabjeesh SJ, Weinberg ZG and Miron J 2015. Effect of ensiling pomegranate pulp with solid additives on chemical composition, intake and digestibility by sheep. Small Ruminant Research 131, 93-98.

Fegeros K, Zervas G, Stamouli S and Apostolaki E 1995. Nutritive value of dried citrus pulp and its effect on milk yield and milk composition of lactating ewes. Journal of Dairy Science 78, 1116-1121.

Hadjipanayiotou M 1999. Feeding ensiled crude olive cake to lactating Chios ewes, Damascus goats and Friesian cows. Livestock Production Science 59, 61-66.

Lanza M, Priolo A, Biondi L, Bella M and Salem H Ben 2001. Replacement of cereal grains by orange pulp and carob pulp in faba bean-based diets fed to lambs: effects on growth performance and meat quality. Animal Research 50, 21-30.

Molina-Alcaide E, Morales-García EY, Martín-García Al, Salem H Ben, Nefzaoui A and Sanz-Sampelayo MR 2010. Effects of partial replacement of concentrate with feed blocks on nutrient utilization, microbial $\mathrm{N}$ flow, and milk yield and composition in goats. Journal of Dairy Science 93, 2076-2087. 
Nudda A, Battacone G, Usai MG, Fancellu S and Pulina G 2006. Supplementation with extruded linseed cake affects concentrations of conjugated linoleic acid and vaccenic acid in goat milk. Journal of Dairy Science 89, 277-282.

Pardo G, del Prado A, Martínez-Mena M, Bustamante MA, Martín JAR, ÁlvaroFuentes $\mathrm{J}$ and Moral R 2017. Orchard and horticulture systems in Spanish Mediterranean coastal areas: Is there a real possibility to contribute to $C$ sequestration? Agriculture, Ecosystems \& Environment 238, 153-167.

Pirmohammadi R, Rouzbehan Y, Rezayazdi K and Zahedifar M 2006. Chemical composition, digestibility and in situ degradability of dried and ensiled apple pomace and maize silage. Small ruminant research 66, 150-155.

Razzaghi A, Naserian AA, Valizadeh R, Ebrahimi SH, Khorrami B, Malekkhahi M and Khiaosa-ard R 2015. Pomegranate seed pulp, pistachio hulls, and tomato pomace as replacement of wheat bran increased milk conjugated linoleic acid concentrations without adverse effects on ruminal fermentation and performance of Saanen dairy goats. Animal Feed Science and Technology 210, $46-55$.

Romero-Huelva $M$ and Molina-Alcaide E 2013. Nutrient utilization, ruminal fermentation, microbial nitrogen flow, microbial abundances, and methane emissions in goats fed diets including tomato and cucumber waste fruits. Journal of animal science 91, 914-923.

Romero-Huelva M, Martín-García Al, Nogales R and Molina-Alcaide E 2013. The effects of feed blocks containing tomato and cucumber by-products on in vitro ruminal fermentation, microbiota, and methane production. J. Anim. Sci 22, 229-237.

Romero-Huelva M, Ramírez-Fenosa MA, Planelles-González R, García-Casado P and Molina-Alcaide E 2017. Can by-products replace conventional ingredients in concentrate of dairy goat diet? Journal of dairy science 100, 4500-4512.

Salem H Ben and Znaidi I-A 2008. Partial replacement of concentrate with tomato pulp and olive cake-based feed blocks as supplements for lambs fed wheat straw. Animal feed science and technology 147, 206-222.

Scerra V, Caparra P, Foti F, Lanza M and Priolo A 2001. Citrus pulp and wheat straw silage as an ingredient in lamb diets: effects on growth and carcass and meat quality. Small Ruminant Research 40, 51-56.

Sedighi- Vesagh R, Naserian AA, Ghaffari MH and Petit H V 2015. Effects of pistachio by- products on digestibility, milk production, milk fatty acid profile and blood metabolites in Saanen dairy goats. Journal of animal physiology and animal nutrition $99,777-787$.

Volanis M, Zoiopoulos P and Tzerakis K 2004. Effects of feeding ensiled sliced oranges to lactating dairy sheep. Small Ruminant Research 53, 15-21.

Volanis M, Zoiopoulos P, Panagou E and Tzerakis C 2006. Utilization of an ensiled citrus pulp mixture in the feeding of lactating dairy ewes. Small Ruminant Research 64, 190-195. 